\title{
EXTINCT TAXA OF EXOTESTAL SEEDS CLOSE TO AUSTROBAILEYALES AND NYMPHAEALES FROM THE EARLY CRETACEOUS OF PORTUGAL
}

\author{
ELSE MARIE FRIIS ${ }^{1, *}$, PETER R. CRANE ${ }^{2,3}$, KAJ RAUNSGAARD PEDERSEN ${ }^{4}$ \\ ${ }^{1}$ Department of Palaeobiology, Swedish Museum of Natural History, Box 50007, SE-104 05 Stockholm, Sweden; \\ e-mail: else.marie.friis@nrm.se. \\ 2 Oak Spring Garden Foundation, 1776 Loughborough Lane, Upperville, Virginia 20184 USA. \\ ${ }^{3}$ School of Forestry and Environmental Studies, Yale University, New Haven, Connecticut 06511 USA. \\ ${ }^{4}$ Department of Geoscience, University of Aarhus, Høegh-Guldbergs Gade 2, DK-8000 Aarhus C Denmark. \\ * corresponding author
}

Friis, E. M., Crane, P. R, Pedersen, K. R. (2018): Extinct taxa of exotestal seeds close to Austrobaileyales and Nymphaeales from the Early Cretaceous of Portugal. - Fossil Imprint, 74(1-2): 135-158, Praha. ISSN 2533-4050 (print), ISSN 2533-4069 (on-line).

\begin{abstract}
Early Cretaceous mesofossil floras from Portugal and North America include a surprising diversity of small, bitegmic angiosperm seeds with a hard exotestal seed coat. This study describes six different kinds of these seeds from three Portuguese mesofossil localities; Vale de Agua, Torres Vedras, and especially from Famalicão, which has yielded a flora exceptionally rich in exotestal seeds. All the seeds are almost smooth with a characteristic jigsaw puzzle-shaped surface pattern that is formed from the strongly undulate anticlinal walls of the sclerenchyma cells that comprise the exotesta. Several specimens have internal details preserved, including remains of a cellular nutritive tissue interpreted as endosperm, and a tiny embryo with two rudimentary cotyledons. Based on differences in details of the seed coat, and configuration of hilum and micropyle, the fossil seeds are assigned to six new genera, as six new species: Gastonispermum portugallicum gen. et sp. nov., Pazlia hilaris gen. et sp. nov., Pazliopsis reyi gen. et sp. nov., Reyispermum parvum gen. et sp. nov., Lusitanispermum choffatii gen. et sp. nov. and Silutanispermum kvacekiorum gen. et sp. nov. The characteristic exotestal cells with undulate anticlinal walls, details of the hilar and micropylar region, together with the tiny dicotyledonous embryos with rudimentary cotyledons, suggest close relationships to seeds of Nitaspermum and Tanispermum described previously from Early Cretaceous mesofossil floras from eastern North America. These exotestal seeds from Portugal and North America indicate the presence of diverse extinct early angiosperms close to the lineages that today include extant Austrobaileyales and Nymphaeales.
\end{abstract}

Key words: fossil embryos, fossil seeds, Illiciaceae, Nymphaeaceae, rudimentary cotyledons, synchrotron radiation X-ray tomographic microscopy (SRXTM)

Received: March 8, 2018 | Accepted: April 23, 2018 | Issued: August 31, 2018

\section{Introduction}

Early Cretaceous mesofossil floras from North America and Portugal have provided an enormous diversity of small angiosperm fruits and seeds. Some of the seeds recovered are orthotropous, bitegmic and endotestal, and have been closely linked to the extant family Chloranthaceae. These include the extinct species Rightcania kvacekii E.M.FrIIS, P.R.CRANE et K.R.PedERSEN and Kvacekispermum rugosum E.M.Fris, P.R.Crane et K.R.Pedersen (described in this issue; Friis et al. 2018a), and species assigned to the extinct genera Canrightia E.M.FriIS et K.R.PEDERSEN and Canrightiopsis E.M.Fris, G.W.Grimm, M.M.Mendes et K.R.Pedersen (Friis and Pedersen 2011, Friis et al. 2015b). However, much more diverse in Early Cretaceous mesofossil floras are anatropous, bitegmic and exotestal seeds similar to those described previously from the small fruits of Couperites K.R.Pedersen, P.R.CrAne, A.N.DrinnAn et E.M.FriIs (Pedersen et al. 1991) and Anacostia E.M.Fris, P.R.Crane et K.R.Pedersen (Friis et al. 1997). Also part of this anatropous, bitegmic and exotestal group are 10 species of exotestal seeds from the Early Cretaceous of eastern North America that have been assigned to the genera Nitaspermum E.M.Fris, P.R.Crane et K.R.Pedersen (Friis et al. 2018c) and Tanispermum E.M.FriIs, P.R.CRANE et K.R.PEDERSEN (Friis et al. 2018b), all of which are characterized by their jigsaw puzzle-shaped surface ornamentation formed by the strongly undulate anticlinal walls of the exotestal cells.

Seeds with seed coat features similar to those of Nitaspermum and Tanispermum, including palisade-shaped sclerenchyma cells of the exotesta with strongly undulate anticlinal walls, are also present in the Early Cretaceous 
of Portgual. Several have been illustrated in earlier studies (Friis et al. 1999, 2011), but most lack formal descriptions and more than 20 different types can be distinguished. Here we describe a selection of these exotestal seeds from Portuguese Early Cretaceous mesofossil floras to illustrate their diversity and assess their systematic relationships. All of these exotestal seeds are small, but vary in their size, shape, surface ornamentation and details of the seed coat. They are assigned to six new genera, Gastonispermum gen. nov., Pazlia gen. nov., Pazliopsis gen. nov., Reyispermum gen. nov., Lusitanispermum gen. nov. and Silutanispermum gen. nov. Their shared features indicate that they are phylogenetically closely related, and all belong to a diverse complex of early angiosperms the only living vestiges of which are the systematically depauperate extant lineages Austrobaileyales and Nymphaeales.

\section{Material and methods}

The fossil seeds described here were recovered from three Early Cretaceous mesofossil floras extracted from unconsolidated terrestrial and fluviatile sediments in the Lusitanian Basin, Portugal. Most of the seeds are from the Famalicão mesofossil flora, but there are also specimens from Vale de Agua and Torres Vedras.

The Vale de Agua mesofossil flora is from sediments assigned to the basal part of the Figueira da Foz Formation, which is indicated to be of late Aptian - early Albian age based on stratigraphic correlations (Dinis et al. 2008). The Famalicão mesofossil flora was extracted from sediments that occur below the basal conglomerates of the Figueira da Foz Formation, and is therefore of late Aptian - early Albian age or older. The Torres Vedras mesofossil flora was recovered from sediments assigned to the lower part of Almargem Formation, which according to Dinis et al. (2008) is of late Barremian - early Aptian age based on stratigraphic correlations (for additional details on the localities and mesofossil floras see also Friis et al. 2010, 2011).

Mesofossils were extracted from sediment samples by sieving in water. Typically 1 or 2 kilograms of sediments were processed for each sample. The organic sieving residual was cleaned of adhering mineral matrix using $\mathrm{HF}, \mathrm{HCl}$ and water following standard procedures (e.g. Friis et al. 2009, 2011). The plant fossils retrieved from the sediment samples include flowers, fruits, seeds and stamens of angiosperms as well as twigs and seeds of conifers, spores, sporangia and vegetative remains of ferns, lycophytes and bryophytes. The fossils are variously preserved, sometimes as charcoal, but most commonly as lignite. Cellular preservation is excellent in many of the specimens. The systematic composition, type of organs and amount of fossil remains recovered from each sample may vary considerably from locality to locality, but also from sample to sample within a single locality. For instance from the Torres Vedras locality, sample 043 and sample 044 were collected close to each other in the same plant-bearing horizon and in the same lithology, but are never-the-less very different, with sample 043 dominated by fruits and seeds and some stamens while sample 044 includes many stamens and pollen lumps together with some fruits and seeds.
The mesofossil flora extracted from the Famalicão sample 025 stands out from all other mesofossil floras collected in the Lusitanian Basin in its exceptional rich and diverse assemblage of angiosperm remains recovered from a small sediment sample of less than $1 \mathrm{~kg}$. Several thousand specimens have been picked out so far and provisionally assigned to more than 100 different species (Eriksson et al. 2000). The plant bearing sediments are fluviatile and plant remains were most likely transported to the deposition basins by water. It is unknown what caused the great concentration of angiosperm fruits and seeds at the Famalicão site, but the plant bearing horizon where sample 025 was collected was a very restricted occurrence. Flowers with delicate floral parts recovered among the plant fragments both in the Famalicão sample and in other mesofossil floras indicate that in these floras the mesofossils had not been exposed to rough physical damage during transportation and that the plants producing the flowers, fruits and seeds may have grown close to the depositional basin.

Seed morphology was studied using a Hitachi S-4300 Field Emission Scanning Electron Microscope at $2 \mathrm{kV}$ at the Swedish Museum of Natural History, Stockholm. Specimens for SEM were mounted on aluminum stubs with nail polish and coated with gold.

Details of seed morphology and anatomy were also studied using attenuation-based synchrotron radiation X-ray tomographic microscopy (SRXTM) at the TOMCAT beamline of the Swiss Light Source of the Paul Scherrer Institute, Villigen, Switzerland (Stampanoni et al. 2006). Textfig. $3 \mathrm{~g}$, h are SEM images, but all other illustrations included in this paper were generated from SRXTM data. Specimens for SRXTM were mounted on brass stubs using nail polish and examined at $10 \mathrm{keV}$ using a sCMOS detector and a 20 $\mu \mathrm{m}$ thick LAG:Ce scintillator screen. Specimens S105218, S170229, S170234, S170238, S174035, S174178, S174179, S174336, S174342, S174343, S174345, S174352, S174353, S174430, S174435, S174467 - S174470, S174472, S174474, S174811, S174819 - S174821, S175044, S175046, S175082 - S175084, S175095, S175096 and S175098 were analyzed using a $10 \times$ objective (isotopic pixel size $0.65 \mu \mathrm{m}$ ). Specimens S171534, S174468 - S174470, S174472, S174495, S174614, S174632, S174633, S174820 were analyzed using a $20 \times$ objective (isotropic pixel size $0.325 \mu \mathrm{m}$ ). More details on the methods are provided in Friis et al. (2014).

The embryo to seed ratio ( $\mathrm{E}: \mathrm{S}$ ) was based on measurements in pixels of the 2D area of embryo and seed inside the integuments using the free software Fiji (Schindelin et al. 2012). Measurements were made on longitudinal orthoslices through the median plane of the seeds (through the raphe) (see Friis et al. 2015a).

All the fossil material and raw data is housed in the palaeobotanical collections of the Department of Palaeobiology, Swedish Museum of Natural History, Stockholm. Specimens mounted for SEM and SXRTM have separate numbers. Unmounted specimens are stored in box-slides with one to numerous specimens under a single number.

New names of fossil plants are being registered in the Plant Fossil Names Registry, which is hosted and operated by the National Museum, Prague for the International Organisation of Palaeobotany (IOP), each with a unique registry number. 

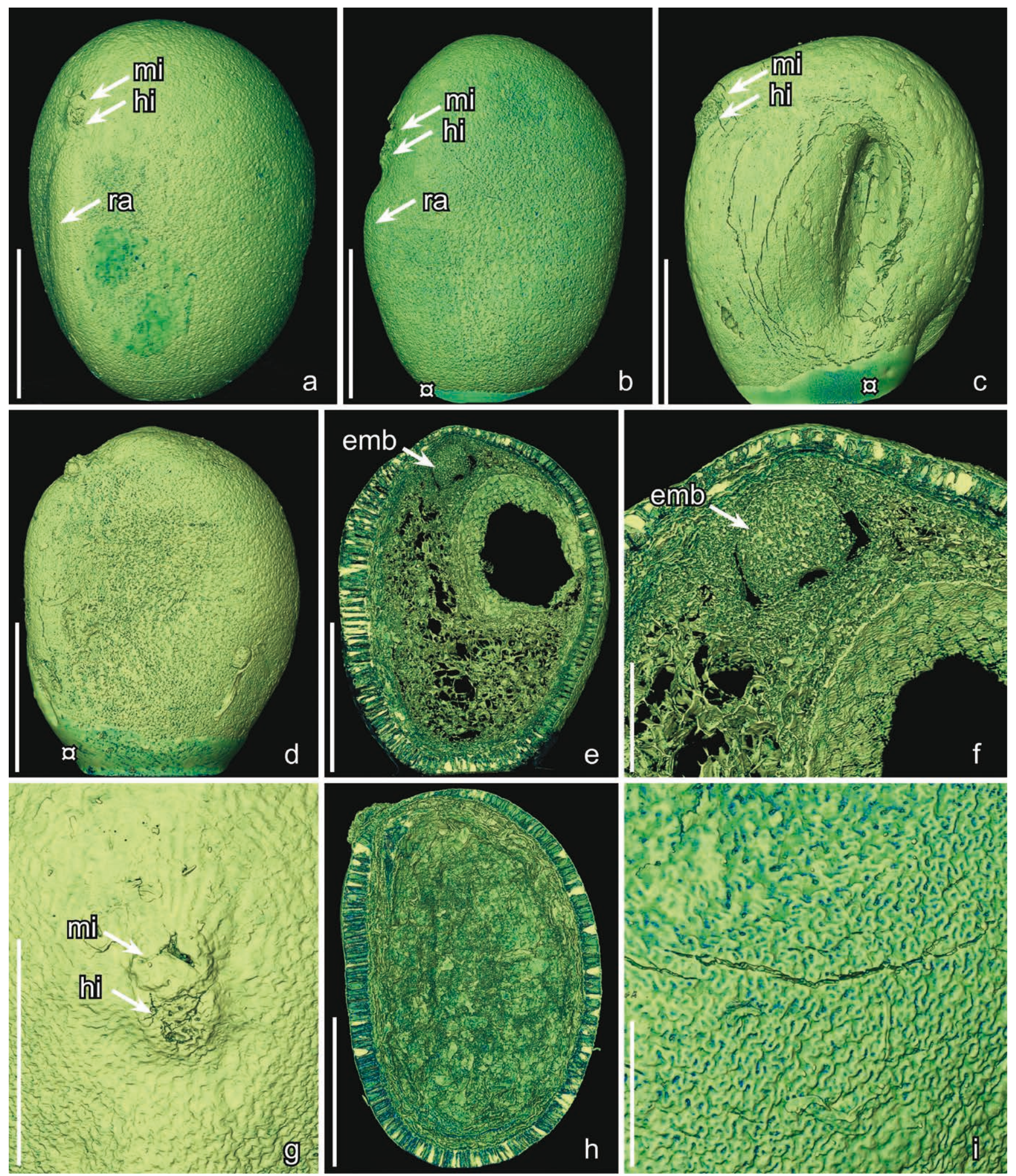

Text-fig. 1. Gastonispermum portugallicum gen. et sp. nov. seeds from the Early Cretaceous Famalicão locality (sample 025), Portugal; Synchrotron radiation X-ray tomographic microscopy (SRXTM, volume renderings). Note remains of mounting media on several seeds (a). a) Seed in oblique view showing seed shape, the slightly raised raphal ridge and the position of hilum (hi) and micropyle (mi) on the raphal side of the seed (S170218). b, c) Seeds in lateral view (b, S170234; c, S175095). d-f) Holotype (S174820); seed in lateral view (d) and cut volume rendering (e, f) through the median plane of the seed showing palisade-shaped sclerenchyma cells of exotesta and remains of embryo (emb) and surrounding nutritive tissue (e, cut between yz0440-0530; $f$, cut between slices yz440-480). g) Hilum (hi) and micropyle (mi) of seed in (1a) showing the Y-shaped micropylar slit in the outer integument. h) Cut volume rendering through the median plane of the seed (cut at yz0492) showing seed coat mainly composed of palisade-shaped cells of the exotesta (S174435). i) Seed surface showing the raised outlines of the undulate anticlinal walls of the exotestal cells (S175045). Scale bars $=500 \mu \mathrm{m}(\mathrm{a}-\mathrm{e}) ; 250 \mu \mathrm{m}(\mathrm{g}) ; 125 \mu \mathrm{m}(\mathrm{f}, \mathrm{i})$. 


\section{Systematic palaeobotany}

\section{Genus Gastonispermum gen. nov.}

Ty p e . Designated here, Gastonispermum portugallicum gen. et sp. nov.

Plant Fossil Names Registry Number. PFN000088 (for new genus).

Etymology. In recognition of Gaston de Saporta $(* 1823, \uparrow 1895)$ for his pioneering contributions to studies of the Mesozoic floras of Portugal.

$\mathrm{D}$ i a g n o s is. Isolated seeds occurring singly. Seeds small, anatropous, bitegmic and exotestal. Seeds bilaterally symmetrical with a dorsiventral plane of symmetry. Seed surface smooth without longitudinal ridges. Raphe distinct, seen externally as a slightly raised rounded ridge that extends from hilum to the chalazal end opposite the micropyle. Hilum and micropyle separated by a narrow zone of sclerenchyma. Hilar scar small, slightly raised without a hilar rim. Micropyle formed by the inner integument (tegmen) and marked on the seed surface by a Y-shaped slit through the outer integument (testa) adjacent to the hilar scar. Testa formed from an outer layer (exotesta) of palisade-shaped sclerenchyma cells and an inner thin layer of thin-walled parenchyma cells (mesotesta/endotesta). Palisade-shaped cells of exotesta with evenly thickened anticlinal walls and a straight lumen. Anticlinal walls of palisade-shaped sclerenchyma strongly undulate toward the inside and toward the outside, resulting in stellateundulate facets and a jigsaw puzzle-like pattern on the seed surface. Tegmen thin. Embryo tiny with two rudimentary cotyledons.

Comments on the genus. Details of the seed coat in Gastonispermum are similar to those of Nitaspermum (Friis et al. 2018c), a genus established for Early Cretaceous seeds from eastern North America. However, there are also important differences, including the shape of the micropylar slit, which is Y-shaped in Gastonispermum but transversely elongate in Nitaspermum. Many features of Gastonispermum seeds, including the Y-shaped micropyle and the strongly undulate anticlinal walls of the exotesta cells, are very similar to seeds of some species of extant Illicium L. (Illiciaceae, Austrobaileyales), but Gastonispermum lacks the pronounced zone of expanded testal tissue between hilum and micropyle (strophiole) that characterizes extant Illicium species (Oh et al. 2003). Similar seeds with strongly undulate anticlinal walls of the exotesta cells and a Y-shaped micropylar slit also occur in Victoria LindL. (Nymphaeaceae; Takahashi et al. 2007), but Victoria is distinguished from Gastonispermum by its much thicker mesotesta and the greater separation between the circular hilar scar and the micropylar slit.

Gastonispermum portugallicum gen. et sp. nov. Text-figs 1-2

Holotype. Designated here, S174820 (Famalicão sample 025; illustrated here in Text-figs 1d-f, 2a, d).

Plant Fossil Names Registry Number. PFN000089 (for new species).

P a r a types. Designated here, S105218, S105220, S170234, S174343, S174430, S174435, S174819, S174821, S175044, S175045, S175082, S175084, S175095, S175100 - S175104 (Famalicão sample 025).

R e p o s it o r y. Palaeobotanical Collections, Department of Palaeobiology, the Swedish Museum of Natural History, Stockholm, Sweden (S).

E ty molog y. The species is named for Portugal where the fossils were collected.

Type locality. Famalicão, Portugal $\left(39^{\circ} 42^{\prime} 16^{\prime \prime} \mathrm{N}\right.$; $\left.8^{\circ} 46^{\prime} 12^{\prime \prime} \mathrm{W}\right)$.

Type stratum and age. Below the Figueira da Foz Formation; Early Cretaceous (late Aptian - early Albian or older).

D i a g n o sis. As for the genus.

D i m e n s i o n s . Length of seeds: $1.2-1.7 \mathrm{~mm}$; width of seeds: $0.8-1.3 \mathrm{~mm}$.

Other s pe c i m e n s. S175108 (Vale de Água sample 330); S175110 (Vale de Água sample 333).

Description and remarks. The species is based on about 230 isolated seeds of which 14 specimens were studied using SRXTM (S105218, S105220, S170234, S174343, S174430, S174435, S174819, S174820, S174821, $\mathrm{S} 175044, \mathrm{~S} 175045, \mathrm{~S} 175082, \mathrm{~S} 175084, \mathrm{~S} 175095)$. There is no information on the fruits in which the seeds were borne.

Text-fig. 2. Gastonispermum portugallicum gen. et sp. nov. seeds from the Early Cretaceous Famalicão locality (sample 025), Portugal; Synchrotron radiation X-ray tomographic microscopy (SRXTM, orthoslices). a) Longitudinal orthoslice (yz0745) through the median plane of the seed (holotype, S174820) showing taller exotestal cells on raphal side, well preserved embryo (em) and partly preserved nutritive tissue. b) Longitudinal orthoslice (xz1355) through the micropylar region perpendicular to the median plane showing the exotestal tissue surrounding the micropyle (mi) forming a Y-shaped micropylar slit (S105218). c) Longitudinal orthoslice (yz0564) through the hilum (hi) and micropyle (mi) in the median plane showing the gradual shortening of the exotestal cells above the micropyle and palisade-shaped sclerenchyma cells lining the micropylar slit (S170234). d) Longitudinal orthoslice (1322) through apical part of seed in the median plane (holotype, S174820) showing embryo with two rudimentary cotyledons (asterisks); note the tiny cells of embryo containing structures we interpret as the fossilized remains of nuclei. e) Longitudinal orthoslice (yz1170) through the apical part of seed in the median plane showing tiny embryo with two rudimentary cotyledons (asterisks) and remains of nutritive tissue with scattered granules that probably representing the remains of protein or lipid bodies; nutritive tissue immediately surrounding embryo is probably endosperm (endo) (S174821). f) Longitudinal orthoslice (xz0590) through apical part of seed perpendicular to the median plane showing the empty space formerly occupied by the embryo, surrounded by cellular nutritive tissue (S174430). g) Transverse orthoslice (xy0969) through the middle part of a seed showing palisade-shaped exotestal cells and remains of mesotesta and tegmen (S175044). Scale bars $=500 \mu \mathrm{m}(\mathrm{a}) ; 250 \mu \mathrm{m}(\mathrm{c}-\mathrm{e}, \mathrm{g}) ; 125 \mu \mathrm{m}(\mathrm{b}, \mathrm{f})$. 

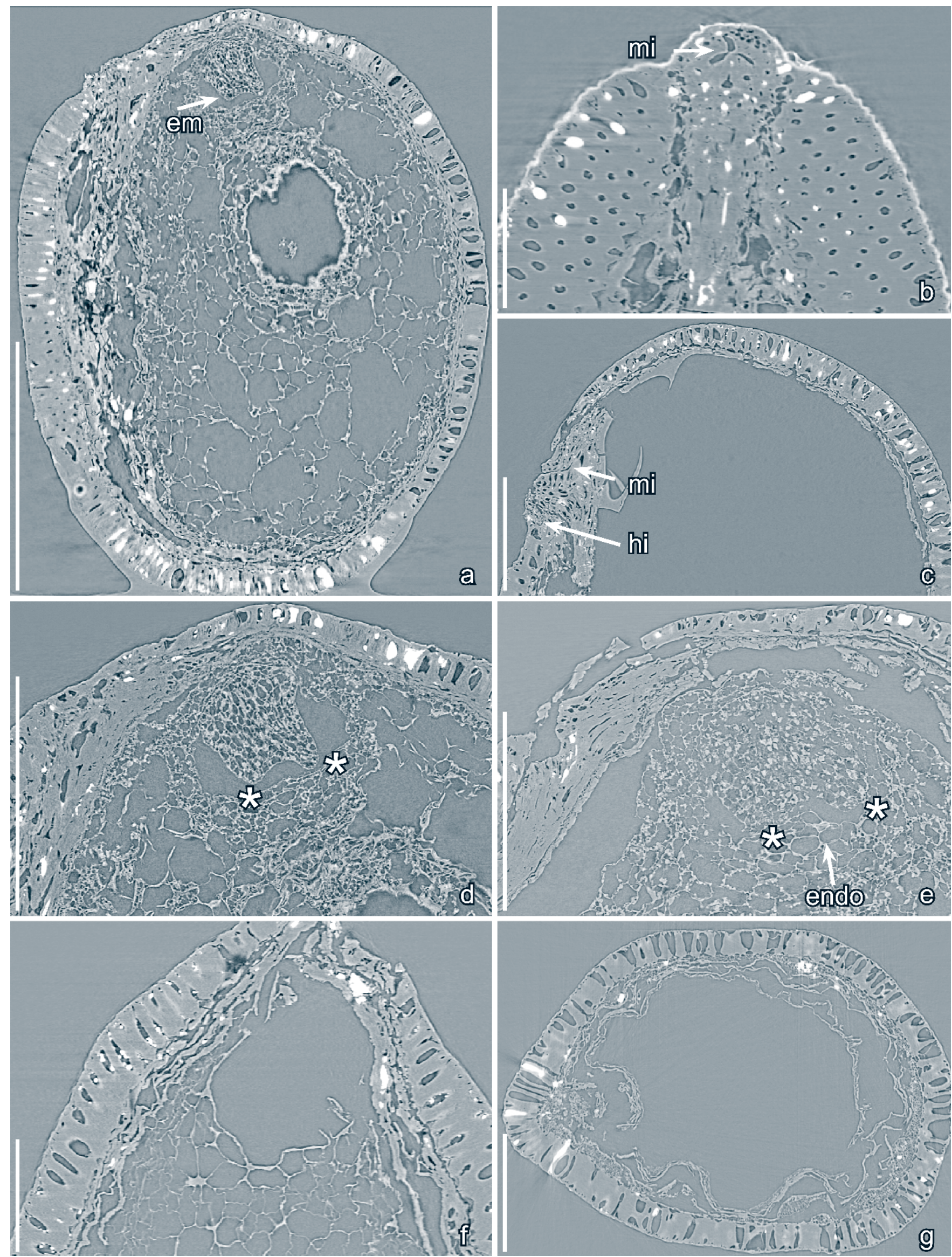

The seeds are small, anatropous, bitegmic and exotestal with bilateral symmetry. They are elliptical in lateral view (Text-figs 1a-e, h, 2a) and also in transverse section (Text- fig. 2g). The seed surface is dull, almost smooth, but with a jigsaw puzzle-shaped pattern formed from the slightly raised undulate anticlinal walls of the exotesta cells. 
Micropyle and hilum are very close together and displaced towards the raphal side of the seed (Text-fig. 1ad). The hilum is small, circular in outline and slightly raised without a hilar rim (Text-fig. 1g). The course of the raphe is distinct on the seed surface and seen as a slightly raised, rounded ridge that extends from hilum to the chalazal end of the seed (Text-fig. 1a, b). The micropyle is formed from the inner integument. The position of the micropyle is marked by a branched, Y-shaped slit in the testa (Text-figs 1g, 2b). Internally the micropylar slit is lined by testal cells on all sides (Text-fig. 2a, b).

The seed coat is composed of a thick exotesta, a thinner mesotesta/endotesta, and a thin tegmen. The exotesta consists of a single layer of tall, columnar sclerenchyma that vary in height from about $55 \mu \mathrm{m}$ laterally and on the antiraphal sides of the seed, to about $80 \mu \mathrm{m}$ over the raphe (Text-figs 1e, h, $2 \mathrm{a}, \mathrm{g})$. In the micropylar region the columnar sclerenchyma cells are shorter and become much shorter towards the micropylar slit (Text-figs 1e, f, h, 2a, c, e). The exotestal cells are arranged in indistinct longitudinal rows. The anticlinal walls of the exotestal cells are thickened, slightly raised on the surface, and of almost even thickness from the outside to the inside, resulting in an almost straight lumen (Text-figs $1 \mathrm{~h}, 2 \mathrm{a}, \mathrm{g})$. Towards the outside and inside they are strongly undulate resulting in stellate-undulate facets and a jigsaw puzzle-like pattern on the surface with rounded, undivided lobes (Text-fig. 1i). Exotestal cells are also undulate over the raphe. Exotesta cells around the micropylar slit are slender and tall (Text-fig. 2c). The mesotesta/endotesta consists of two or three layers of collapsed parenchyma cells with thick cell walls (Text-fig. 2a). The tegmen is thin and composed of cells that are collapsed over most of the seed, but more robust and slightly thickened in the micropylar region.

Nutritive tissue is partly preserved in five of the specimens that were studied using SRXTM. Two of these specimens (S174820, S174821) also had a complete embryo preserved. In both cases the embryo is tiny, about $130 \mu \mathrm{m}$ long and 130 $\mu \mathrm{m}$ broad, with two rudimentary cotyledons and an embryo to seed $(\mathrm{E}: \mathrm{S})$ ratio of about 0.02 . The embryo is composed of cells that are much smaller than the surrounding nutritive tissue. Each cell contains a dense, central structure that may be the fossilized remains of a nucleus (Text-figs 1e, f, 2a, d, e). The nutritive tissue is cellular, consisting of isodiametric and thin-walled cells, about $40 \mu \mathrm{m}$ in diameter (Text-fig. $2 \mathrm{a}, \mathrm{e}, \mathrm{f})$. Cell walls are slightly undulating or straight. In some specimens the cells of the nutritive tissue are empty (Text-fig. 2f), but in other cases these cells are filled by small granules. These granules are often clustered close to the cell walls (Text-fig. 2e) and we interpret them to be the remains of protein or lipid bodies. We interpret the nutritive tissue immediately surrounding the embryo as endosperm (Textfig. 2e), but the continuity of this inner tissue with the bulk of the nutritive tissue in the outer parts of the seed is not clear, and thus the possibility that the outer tissues may be perisperm cannot be definitively excluded.

\section{Genus Pazlia gen. nov.}

Ty p e. Designated here. Pazlia hilaris gen. et sp. nov.

Plant Fossil Names Registry Number. PFN000090 (for new genus).
E ty mology. From Greek $\pi \alpha \zeta \lambda$ : jigsaw puzzle, for the distinct jigsaw puzzle-like outline of the facets of the exotestal cells.

Generic diagnosis. Isolated seeds occurring singly. Seeds small, anatropous, bitegmic and exotestal. Seeds bilaterally symmetrical with dorsiventral plane of symmetry. Seed surface smooth without longitudinal ridges. Raphe distinct, seen externally as a raised, rounded ridge that extends from hilum to the chalazal end opposite the micropyle. Hilum and micropyle separated by a broad zone of testal sclerenchyma. Hilar scar large, narrowly elongate with abundant sclerenchyma tissue beneath the scar and lacking a hilar rim. Micropyle formed by the inner integument (tegmen) and marked on the seed surface by a transverse slit through the outer integument (testa) adjacent to the hilar scar. Testa formed from an outer layer (exotesta) of palisade-shaped sclerenchyma cells and an inner thin layer of thin-walled parenchyma cells (mesotesta/ endotesta). Palisade-shaped cells of exotesta with evenly thickened anticlinal walls and a straight lumen. Anticlinal walls of the exotesta cells strongly undulate toward the inside and toward the outside, resulting in stellate-undulate facets and a jigsaw puzzle-like pattern on the seed surface. Tegmen thin.

Comments on the genus. Seeds assigned to Pazlia are similar to seeds of Gastonispermum, Pazliopsis, Reyispermum, Lusitanispermum and Silutanispermum in the shape of the exotestal cells, but seeds of Pazlia are much smaller than those of Gastonispermum, Lusitanispermum and Silutanispermum, and they also have a strong expanded sclerenchyma tissue under the hilar scar. Seeds of Pazlia further differ from those of Gastonispermum, Reyispermum, Lusitanispermum and Silutanispermum in details of the micropyle and in the elongated hilar scar, but in these features are more similar to seeds of Pazliopsis. In details of the seed coat, and also the large ovate hilar scar, seeds of Pazlia also resemble those of extant Illicium (Illiciaceae), but lack the characteristic strophiole seen in the extant genus.

\section{Pazlia hilaris gen. et sp. nov.} Text-figs $3 \mathrm{a}-\mathrm{e}, 4 \mathrm{a}, \mathrm{b}$

Hol otype. Designated here, S175096 (Famalicão sample 025 ; illustrated here on Text-figs $3 \mathrm{a}-\mathrm{d}, 4 \mathrm{a}, \mathrm{b}$ ).

Plant Fossil Names Registry Number. PFN000091 (for new species).

Paratypes. Designated here, S174336, S174342, S175083, S175098, S175105, S175106 (Famalicão sample 025).

R e p o s i t o r y. Palaeobotanical Collections, Department of Palaeobiology, the Swedish Museum of Natural History, Stockholm, Sweden.

E t y m o lo g y. From Latin: hilaris, relating to the hilum to emphasis the large hilar scar and strongly developed sclerenchyma tissue under hilum.

Ty p e locality. Famalicão, Portugal (3942'16"N; $\left.8^{\circ} 46^{\prime} 12^{\prime \prime} \mathrm{W}\right)$. 

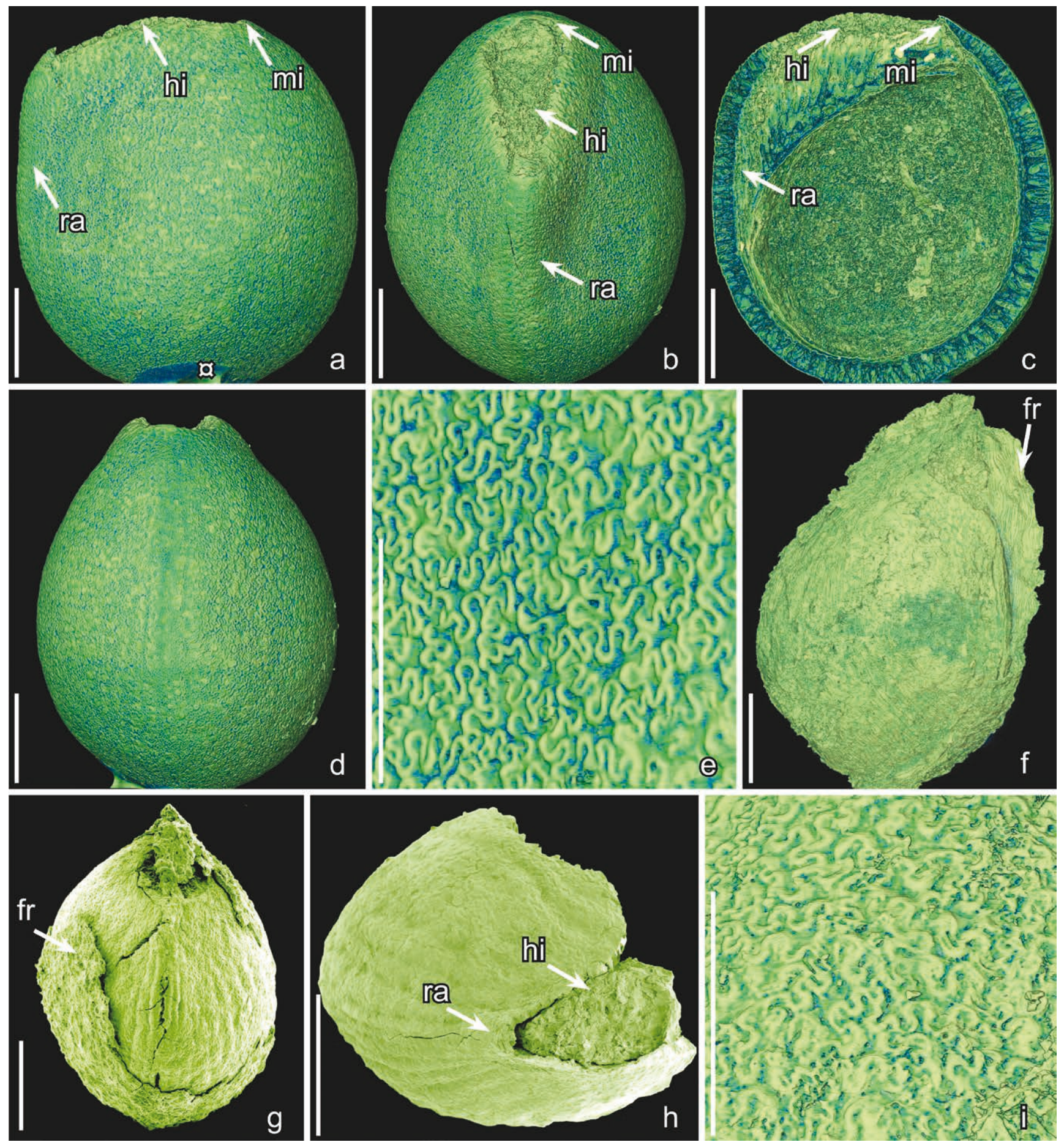

Text-fig. 3. Pazlia hilaris gen. et sp. nov. (a-e) from the Early Cretaceous Famalicão locality (sample 025), Portugal (holotype, S175096) and Pazliopsis reyi gen. et sp. nov. (f-i) from the Early Cretaceous Torres Vedras locality, Portugal; Synchrotron radiation X-ray tomographic microscopy (SRXTM, volume renderings a-f, i) and scanning electron microscopy (SEM, g, h). a, b) Seed in lateral (a) and oblique apical (b) views showing the truncate hilar-micropylar region; note prominent hilar scar (hi) and micropyle (mi) at the seed apex and the raphe (ra) seen as slightly raised ridge; remains of mounting media (a). c) Cut volume rendering (cut at yz0647) showing course of raphe ( $\mathrm{ra}$ ), hilar scar (hi) and micropyle (mi); note the strongly radially elongated cells below the hilar scar. d) Seed in antiraphal view. e) Seed surface showing the raised undulate anticlinal walls of the exotestal cells. f) Seed enclosed in remains of thin-walled fruit (fr) (S174632, Torres Vedras sample 298). g) Holotype, seed enclosed in remains of fruit (fr); raphal view showing the faintly ribbed surface of the seed (S171534, Torres Vedras sample 043). h) Apical view of seed fragment showing hilar scar (hi), position of raphe ( $\mathrm{ra}$ ) and the ribbed seed surface (S136683, Torres Vedras sample 044). i) Seed surface showing the raised undulate anticlinal walls of the exotestal cells (S171534; Torres Vedras sample 043). Scale bars $=250 \mu \mathrm{m}(\mathrm{a}-\mathrm{d}, \mathrm{f}-\mathrm{h}) ; 125 \mu \mathrm{m}(\mathrm{e}, \mathrm{i})$.

Type stratum and age. Below the Figueira da Foz Formation; Early Cretaceous (late Aptian - early Albian or older).
D i a g n o s is. As for the genus.

D i m e n s i o n s . Length of seeds: $1.1-1.4 \mathrm{~mm}$; width of seeds: $0.9-1.2 \mathrm{~mm}$. 

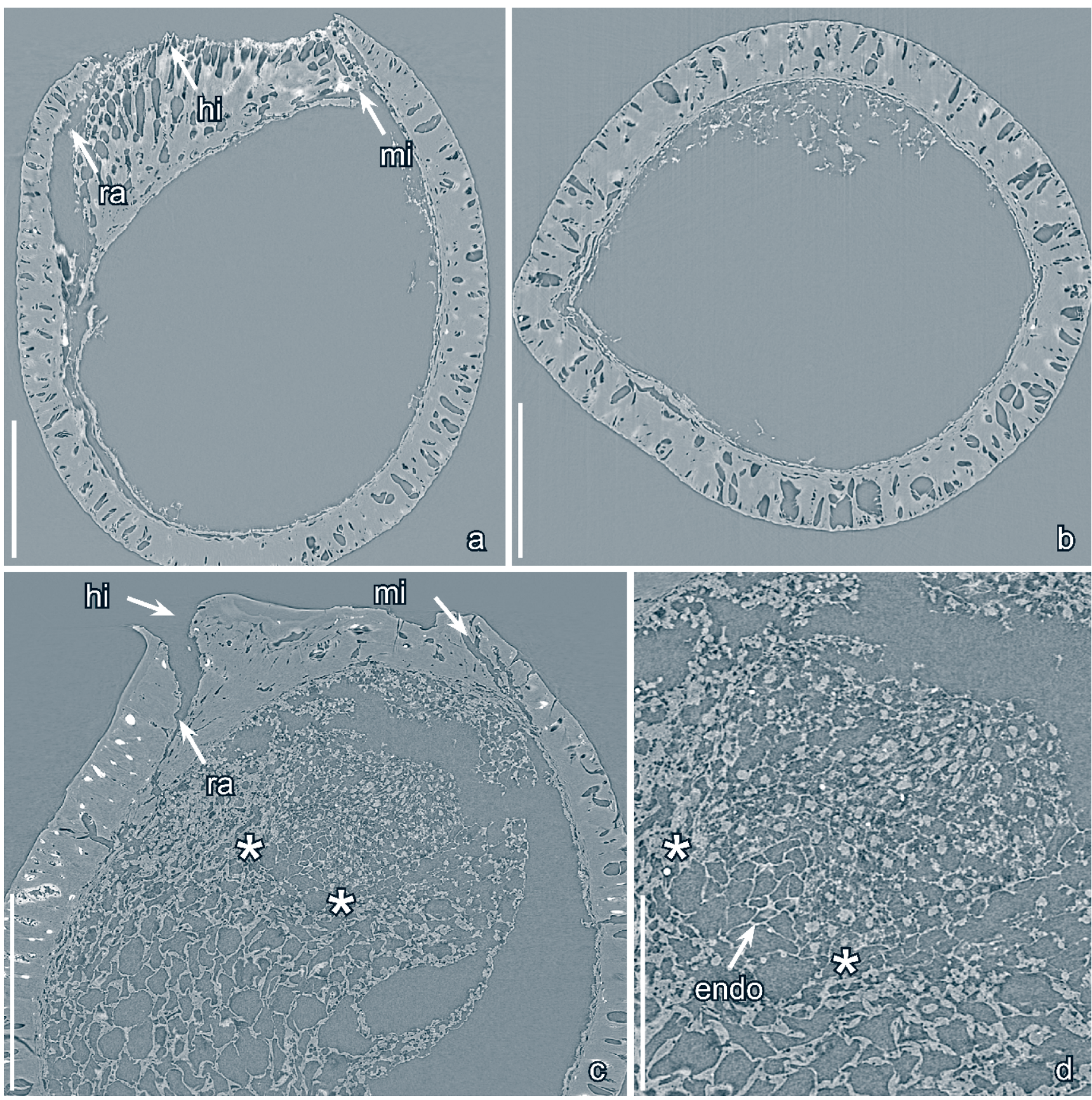

Text-fig. 4. Pazlia hilaris gen. et sp. nov. (a, b) from the Early Cretaceous Famalicão locality (sample 025), Portugal (holotype, S175096) and Pazliopsis reyi gen. et sp. nov. (c, d) from the Early Cretaceous Torres Vedras locality (sample 038), Portugal (S174614); Synchrotron radiation X-ray tomographic microscopy (SRXTM, orthoslices). a) Longitudinal orthoslice (xy0984) through the median plane of the seed showing the strongly thickened sclerenchyma under the hilar scar (hi), micropylar slit (mi) and the raphe (ra); note cells of exotesta are almost equally tall on both raphal and anti-raphal sides of the seed and gradually become shorter towards the micropyle. b) Transverse orthoslice (xy0984) through middle of seed showing the thickened cells of the exotesta; note that cells of the exotesta are almost equally tall on both raphal and anti-raphal sides. c) Longitudinal orthoslice (yz0812) through apical part of seed in the median plane showing embryo with two rudimentary cotyledons (asterisks) and surrounding nutritive tissue; note the tiny cells of embryo with central structures we interpret as the fossilized remains of nuclei. d) Detail of (4c) showing tiny embryo with two rudimentary cotyledons (asterisks); nutritive tissue immediately surrounding the embryo is interpreted as endosperm (endo); whether there is any delimitation between this inner endosperm and the outer part of the nutritive tissues is not clear. Scale bars $=250 \mu \mathrm{m}(\mathrm{a}-\mathrm{c}) ; 125 \mu \mathrm{m}(\mathrm{d})$.

Other materia l. S175109 (Vale de Água 330).

Description and remarks. The species is based on about 20 seeds of which five were studied using SRXTM (S174336, S174342, S175083, S175096, S175098). All seeds are isolated and there is no information on the fruit in which they were borne. The seeds are small, anatropous, bitegmic and exotestal with bilateral symmetry. The seed surface is almost smooth with a jigsaw puzzle-like pattern formed from the raised undulate anticlinal walls of the exotesta cells. The seeds are almost circular in lateral view with a truncate hilar-micropylar region (Text-figs 3a-c, 4a), 
and they are broadly elliptical in transverse section (Textfigs $3 b, 4 b)$.

The micropyle and hilum are separated by a broad zone of sclerenchyma tissue beneath the very large and distinct hilar scar (Text-figs 3a-c, 4a). This hilar sclerenchyma is strongly expanded toward the inside of the seed by cells that are thin-walled, elongate and radiate perpendicular to the hilar scar (Text-figs 3c, 4a). The hilum lacks a rim. The course of the raphe is distinct on the seed surface and seen as a slightly raised, rounded ridge extending from hilum to the chalazal end of the seed (Text-fig. 3b, c). The micropyle is formed from the inner integument, and seen on the seed surface as a narrow slit. There is a strongly thickened zone of sclerenchyma cells between micropyle and raphe (Text-figs 3b, 4a).

Most of the seed coat is composed of exotesta, which is one cell layer deep. The mesotesta/endotesta and tegmen are typically collapsed. The exotesta is one cell layer deep and consists of columnar sclerenchyma cells that are about 105 $\mu \mathrm{m}$ tall over most of the seed, but that gradually become shorter towards the hilar-micropylar region (Text-fig. 4a, b). The exotestal cells are arranged in longitudinal rows over the raphe and on the anti-raphal side, but otherwise their arrangement appears irregular. The anticlinal walls of the exotestal cells are thickened and of almost even thickness from the outside to the inside resulting in an almost straight lumen (Text-fig. 4a, b). They are strongly undulate towards the outside and inside forming a jigsaw puzzle-like pattern on the surface with rounded, deep, sometimes bifurcate, lobes in the stellate-undulate facets (Text-fig. 3d). The cell walls are also undulate over the raphe and in the micropylar region.

Patchy remains of cellular nutritive tissue were observed in one of the specimens studied using SRXTM, but none of the specimens show sufficient internal details to reveal the size or nature of the embryo.

\section{Genus Pazliopsis gen. nov.}

Ty p e. Designated here, Pazliopsis reyi gen. et sp. nov.

Plant Fossil Names Registry Number. PFN000092 (for new genus).

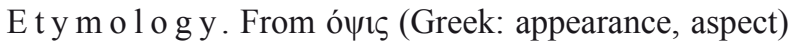
to indicate close similarity in morphological appearance to seeds of Pazlia.

D i a g n o s is . Fruit thin-walled, one-seeded. Seeds small, anatropous, bitegmic and exotestal. Seeds bilaterally symmetrical with dorsiventral plane of symmetry. Seed surface with faint longitudinal ridges. Raphe indistinct externally. Hilum and micropyle separated by broad zone of testal sclerenchyma. Hilar scar large, elongate and prominent with expanded testal tissue beneath the hilar scar, lacking a hilar rim. Micropyle formed by the inner integument (tegmen) and marked on the seed surface by a transverse slit through the outer integument (testa) adjacent to the hilar scar. Testa formed from an outer layer (exotesta) of palisade-shaped sclerenchyma cells and an inner thin layer of thin-walled parenchyma cells (mesotesta/ endotesta). Palisade cells of exotesta with evenly thickened anticlinal walls and a straight lumen. Anticlinal walls of palisade-shaped sclerenchyma strongly undulate toward the inside and toward the outside, resulting in stellate-undulate facets and a jigsaw puzzle-like pattern on the seed surface. Tegmen thin.

Comments on the genus. Seeds assigned to Pazliopsis are similar to those of Pazlia in their large hilar scar with expanded sclerenchyma tissue below. However, the sclerenchyma cells in Pazlia radiate perpendicular to the seed surface and is much thicker than in Pazliopsis. Pazliopsis also differs from Pazlia, as well as the other taxa described here, in the ribbed seed surface. A large, distinct hilar scar, as seen in Pazliopsis, also occurs in the seeds of Illicium, but Pazliopsis lacks the strophiole that is typical of Illicium species.

\section{Pazliopsis reyi gen. et sp. nov. Text-figs $3 \mathrm{f}-\mathrm{i}$, 4c, d}

H o l o t y p e. Designated here, S171534 (Torres Vedras sample 043; illustrated here on Text-fig. $3 \mathrm{~g}$ ).

Plant Fossil Names Registry Number. PFN000093 (for new species).

$\mathrm{P}$ a r a t y p e s . Designated here, S174735 (Torres Vedras sample 043), S174636, S174637, S175024 (Torres Vedras sample 044), S175120 (Torres Vedras sample 144), S174632 (Torres Vedras sample 298).

R e p o s i t o r y. Palaeobotanical Collections, Department of Palaeobiology, the Swedish Museum of Natural History, Stockholm, Sweden.

E ty m o l o gy. In recognition of Jacques Rey $(* 1940$, $\dagger 2018$ ) for his important contributions to understanding the Cretaceous geology of Portugal.

Type locality. Torres Vedras, Portugal (NE of Forte de Forca; $39^{\circ} 06^{\prime} 13^{\prime \prime} \mathrm{N}, 9^{\circ} 14^{\prime} 47^{\prime \prime} \mathrm{W}$ ).

Type stratum and age. Lower part of the Almargem Formation; Early Cretaceous (late Barremian early Aptian).

D i a g no sis. As for the genus.

Dimensions. Length of fruit: $1.1 \mathrm{~mm}$; length of seeds: $0.7-0.9 \mathrm{~mm}$; width of seeds: $0.66-0.84 \mathrm{~mm}$.

Description and remarks. The species is based on two fruits and 30 isolated seeds. Four specimens (S171534, S174614, S174632, S174633) were studied using SRXTM. The fruits or fruitlets are small and each contains a single seed (Text-figs 3f, g, 4c, d). They are isolated from the floral receptacle and it is unknown whether they were from monocarpellate gynoecia or multicarpellate gynoecia that were apocarpous. The fruit wall is thin, collapsed and partly abraded exposing the seed. It consists of an outer zone of small thin-walled cells and an inner zone of obliquely arranged, longitudinally elongate, fibers (Text-fig. 3f). The fibrous inner zone suggests that the fruit was dry.

The seeds are small, anatropous, bitegmic and exotestal with bilateral symmetry, ovate to almost circular in lateral view with a truncate profile at the hilar-micropylar end of the seed (Text-fig. 3f, g). The hilar scar is large and ovate 
in outline and lacks a hilar rim (Text-fig. 3h). Where the raphal bundle enters the seed the micropyle and hilum are separated by expanded sclerenchyma tissue beneath the hilar scar (Text-fig. 4c), and marked on the seed surface by a transverse slit through the outer integument (testa) adjacent to the hilar scar.

The seed coat is mainly comprised of the exotesta, which consists of a single layer of tall, columnar sclerenchyma cells. These cells are about $100 \mu \mathrm{m}$ tall over most of the seed but gradually become shorter towards the hilarmicropylar region (Text-fig. 4c). The anticlinal walls of the exotestal cells are thickened, and of almost even thickness from the outside to the inside resulting an almost straight lumen (Text-fig. 4c). The anticlinal walls of the exotestal cells are strongly undulate towards the outside and inside forming a jigsaw puzzle-like pattern on the seed surface with rounded, deep, undivided lobes (Text-fig. 3i). The cell walls are also undulate over the raphe and in the micropylar region. The inner layers of the testa (mesotesta/endotesta) and the tegmen, which is poorly preserved in the micropylar region, are composed of thin walled cells that are typically collapsed.

One specimen has well-preserved nutritive tissue and an embryo (Text-fig. 4c, d), and another specimen has a remains of the embryo preserved. In both cases the embryo is tiny, with two rudimentary cotyledons (Text-fig. $4 \mathrm{c}, \mathrm{d})$. The embryo to seed $(\mathrm{E}: \mathrm{S})$ ratio is about 0.02 . As in Gastonispermum portugallicum, the cells of the embryo are much smaller than those of surrounding nutritive tissue (Text-fig. 4c, d), and each contains a central structure that we interpret as the probable remains of a nucleus (Text-fig. $4 \mathrm{~d}$ ). The nutritive tissue immediately surrounding the embryo consists of equiaxial cells with thin-walled, straight to slightly wavy cells walls (Text-fig. 4d). This tissue is clearly endosperm. However, the transition between these inner thin-walled endosperm cells and the bulk of the surrounding nutritive tissue is not well preserved so it is uncertain whether all the nutritive tissue is endosperm or whether the outer part of the nutritive tissue could be perisperm.

\section{Reyispermum gen. nov.}

Ty p e. Designated here, Reyispermum parvum gen. et sp. nov.

Plant Fossil Names Registry Number. PFN000094 (for new genus).

E ty m o log y. In recognition of Jacques Rey (*1940, $\dagger 2018$ ) for his important contributions to understanding the Cretaceous geology of Portugal.

$\mathrm{D}$ i a g n o s is. Isolated seeds occurring singly. Seeds tiny, anatropous, bitegmic and exotestal. Seeds bilaterally symmetrical with dorsiventral plane of symmetry. Seed surface smooth without longitudinal ridges. Raphal region distinct, seen externally as a slightly raised rounded ridge that extends from the hilum to the chalazal end opposite the micropyle. Hilum and micropyle separated by a moderate zone of testal sclerenchyma. Hilar scar small, circular without a rim. Micropyle formed by the inner integument (tegmen) and marked on the seed surface by a transverse slit through the outer integument (testa) adjacent to hilar scar. Testa formed from an outer layer (exotesta) of palisade-shaped sclerenchyma cells and an inner thin layer of thin-walled parenchyma cells (mesotesta/endotesta). Testa bulging below hilum. Palisade-shaped cells of exotesta with evenly thickened anticlinal walls and a straight lumen. Anticlinal walls of exotestal cells strongly undulate toward the inside and toward the outside, resulting in stellate-undulate facets and a jigsaw puzzle-like pattern on the seed surface except in the micropylar region where the anticlinal walls are straight and the outer facets polygonal. Tegmen thin.

Comments on the genus. Seeds assigned to Reyispermum are similar to those of Pazlia and Pazliopsis, but much smaller and the sclerenchyma tissue beneath the hilum is much less prominent. Seeds of Reyispermum are also similar in wall structure to the seeds of the extinct genus Illiciospermum FrUMIN et E.M.FRIIS, described from the early Late Cretaceous of Kazakhstan (Frumin and Friis 1999), as well as seeds of extant Illicium (Illiciaceae) (Oh et al. 2003). The slight bulge in the hilar-micropylar area resembles the strophiole seen in Illiciospermum and Illicium, but in these two genera the strophiole is more prominent and distinctly bulging and also clearly separates the hilum and micropyle. In Reyispermum the slight bulge in the hilar-micropylar area is positioned below the hilum.

\section{Reyispermum parvum gen. et sp. nov. Text-figs 5, 6}

H o l o t y p e. Designated here, S174178 (Vale de Água sample 141; illustrated here on Text-figs 5a-c, i, 6a, b).

Plant Fossil Names Registry Number. PFN000094 (for new species).

P aratypes. Designated here, S174179, S175111 (Vale de Água sample 141), S174495 (Vale de Água sample 300).

R e p o s i t o r y. Palaeobotanical Collections, Department of Palaeobiology, the Swedish Museum of Natural History, Stockholm, Sweden.

E t y m o l o g y. From Latin: parvus, small relating to the small size of the seeds.

Ty pe loc a lity. Vale de Água, Portugal $\left(39^{\circ} 37^{\prime} 15^{\prime \prime} \mathrm{N}\right.$, $\left.08^{\circ} 51^{\prime} 30^{\prime \prime} \mathrm{W}\right)$.

Type stratum and age. Basal part of the Figueira da Foz Formation; Early Cretaceous (late Aptian - early Albian).

Di a g n o s is. As for the genus.

D i m e n s i o n s . Length of seeds: $0.44-0.52 \mathrm{~mm}$; width of seeds: $0.28-0.5 \mathrm{~mm}$.

Description and remarks. The species is based on about eight isolated seeds of which three (S174178, S174179, S174495) were studied using SRXTM. All seeds are isolated and there is no information on the fruit in which they were borne. The seeds are tiny, anatropous, bitegmic and exotestal. They are broadly ovate in lateral view, bilaterally symmetrical with dorsiventral plane of symmetry, and sometimes slightly compressed laterally (Text-fig. 5ah). The raphal region is seen on the outside as a slightly raised rounded ridge (Text-fig. 5c, g, h). 

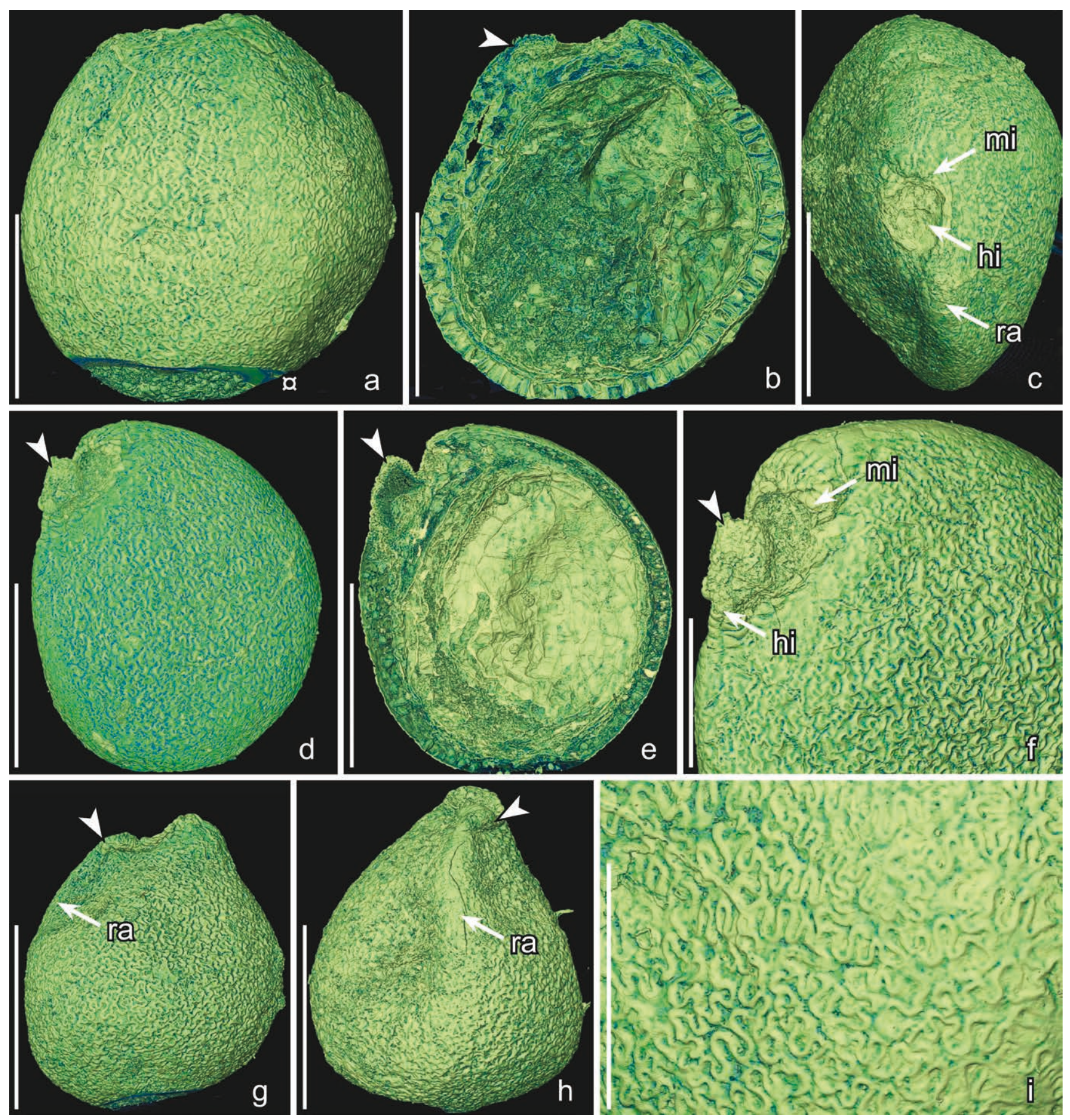

Text-fig. 5. Reyispermum parvum gen. et sp. nov. seeds from the Early Cretaceous Vale de Água locality, Portugal; Synchrotron radiation X-ray tomographic microscopy (SRXTM, volume renderings). a) Holotype (S174178; Vale de Agua sample 141) in lateral view showing shape and cell pattern; remains of mounting media (a). b) Cut volume rendering of seed (cut at yz0553) showing the slightly raised tissue immediately adjacent to the lower edge of the hilum (arrow head) and palisade-shaped cells of exotesta. c) Apical view of seed showing hilar depression (hi), position of micropylar slit (mi) and the slightly raised raphal ridge (ra). d) Seed in lateral view showing raised tissue immediately adjacent to the lower edge of the hilum (arrow head) (S174495, Vale de Água sample 300). e) Cut volume rendering (cut at yz0500) of the seed in (5d) showing the raised tissue (arrow head) immediately adjacent to the lower edge of the hilum and sclerenchyma cells of exotesta. $f$ ) Detail of seed in (5d) showing micropylar slit (mi), hilum (hi) and raised tissue (arrow head) immediately adjacent to the lower edge of the hilum. g, h) Seed in lateral view (g) and view towards raphe (h) showing seed shape, the raised tissue below hilum (arrow head) and the raphal ridge (ra); note pointed micropylar area (S174179, Vale de Água sample 141). i) Seed surface of seed in (5d) showing the raised outlines of the undulate anticlinal walls of the exotestal cells. Scale bars $=250 \mu \mathrm{m}(\mathrm{a}-\mathrm{e}, \mathrm{g}, \mathrm{h}) ; 125 \mu \mathrm{m}(\mathrm{f}, \mathrm{i})$.

The hilum and micropyle are separated by a zone of testal tissue. The hilum lacks a rim and is seen as a small rounded depression (Text-fig. 5b, c). The hilar tissue is slightly expanded inside. The micropyle is formed by the inner integument (tegmen) and marked on the seed surface by a transverse slit through the outer integument (testa) (Text-figs 5c, f, 6b). Internally the micropylar slit is lined on all sides by testal cells. 

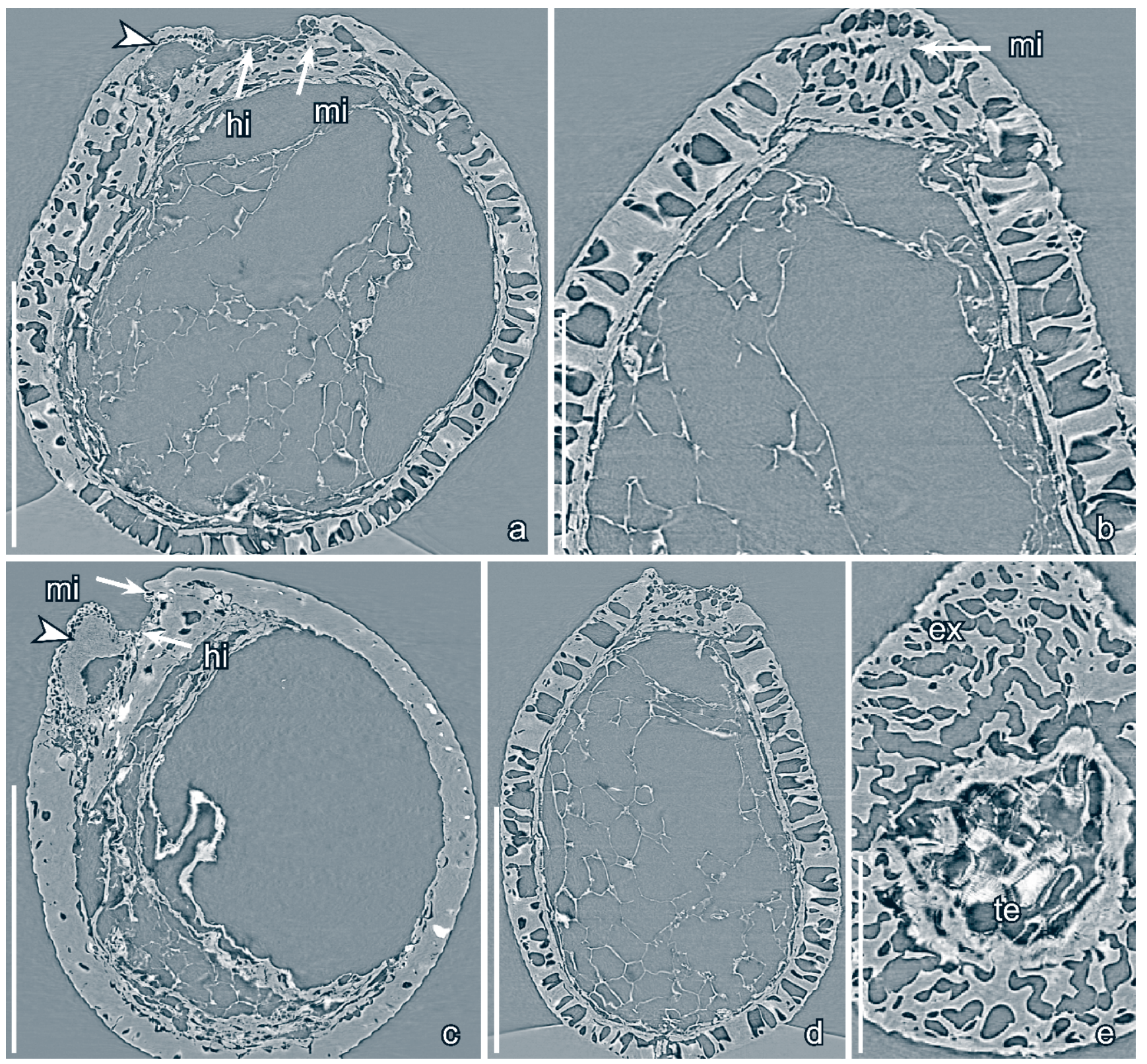

Text-fig. 6. Reyispermum parvum gen. et sp. nov. seeds from the Early Cretaceous Vale de Água locality, Portugal (a, b, d, e: sample 141, c: sample 300); Synchrotron radiation X-ray tomographic microscopy (SRXTM, orthoslices). a) Longitudinal orthoslice (yz0563) through the median plane of the seed (holotype, S174178) showing the palisade-shaped cells of exotesta and collapsed inner parts of seed coat, raised exotestal tissue (arrow head) immediately adjacent to the lower edge of the hilum (hi), micropyle (mi) and remains of cellular nutritive tissue. b) Longitudinal orthoslice (xz0659) through the micropylar region perpendicular to the median plane showing the exotestal tissue surrounding the transverse micropyle slit (mi). c) Longitudinal orthoslice (yz0500) through the median plane of the seed (S175095) showing raised tissue (arrow head) immediately adjacent to the lower edge of the hilum (hi), micropyle (mi) and poorly preserved cells of the seed coat. d) Longitudinal orthoslice (xz0810) through middle part of seed perpendicular to the median plane (S174178) showing seed coat and remains of cellular nutritive tissue. e) Tangential and longitudinal orthoslice (xz0162) through the seed coat of holotype (S174178) showing thickened, undulate cell walls of exotesta (ex) and the short, thin-walled cells of tegmen (te) with a finely striate wrinkled surface. Scale bars $=250 \mu \mathrm{m}(\mathrm{a}, \mathrm{c}, \mathrm{d}) ; 125 \mu \mathrm{m}(\mathrm{b}, \mathrm{e})$.

The testa consists of an outer layer of palisade-shaped sclerenchyma cells and an inner layer of thin-walled parenchyma cells (Text-figs 5b, e, 6a-e). The palisadeshaped cells of the exotesta are about $45 \mu \mathrm{m}$ tall over most of the seed but gradually become shorter towards the micropyle and hilum; in the hilar region the thin exotesta is sometimes loosened forming a slightly bulging structure (Text-figs $5 \mathrm{~b}$, $\mathrm{d}-\mathrm{h}, 6 \mathrm{a}, \mathrm{c})$. The anticlinal cell walls of the exotesta cells are evenly thickened walls and the lumen is more or less straight (Text-fig. 6a, b, d). The outer and inner parts of the anticlinal walls are strongly undulate and slightly raised resulting in stellate-undulate facets and a jigsaw puzzle-like pattern on the seed surface (Text-fig. 5a, d, f-i) except in the micropylar region where the anticlinal walls are straight and the outer facets polygonal (Text-fig. 5f). The lobes of the exotestal walls are deep and sometimes bifurcated. The tegmen is thin, but thickened around the micropyle and composed of rectangular epidermal cells with a striate wrinkled surface that are often collapsed (Text-fig. 6e). 
None of the specimens observed using SRXTM had an embryo preserved, but the irregular cavity in the nutritive tissue, which is in the appropriate position for the embryo, suggests that the embryo was tiny. The nutritive tissue consists of thin-walled and equiaxial cells, about $45 \mu \mathrm{m}$ in diameter (Text-fig. 6d).

\section{Genus Lusitanispermum gen. nov.}

T y p e. Designated here, Lusitanispermum choffatii gen. et sp. nov.

Plant Fossil Names Registry Number. PFN000096 (for new genus).

Etymology. From the Roman province Lusitania that included the part of Portugal where the fossils were collected.

D i a g n o s is. Isolated seeds occurring singly. Seeds small, anatropous, bitegmic and exotestal. Seeds bilaterally symmetrical with dorsiventral plane of symmetry. Seed surface smooth without longitudinal ridges. Raphe indistinct externally. Hilum and micropyle close together separated by a narrow zone of testal sclerenchyma. Hilar scar small without a hilar rim. Micropyle formed by the inner integument (tegmen) and marked on the seed surface by a transverse slit through the outer integument (testa) adjacent to the hilar scar. Testa formed from an outer layer (exotesta) of palisadeshaped sclerenchyma cells, and an inner thick layer of large parenchyma cells (mesotesta/endotesta). Palisade-shaped cells of exotesta with unevenly thickened walls that are thick towards the outside, thin towards the inside, and have a conical lumen. Exotesta thick adjacent to the hilum forming a bulging zone that may be two-parted. Anticlinal walls of palisade-shaped sclerenchyma strongly undulate toward the inside and toward the outside, resulting in stellate-undulate facets and a jigsaw puzzle-like pattern on the seed surface except over the raphe and around the micropyle where the cell walls are straight and facets polygonal. Tegmen thin. Embryo tiny, with two rudimentary cotyledons.

Comments on the genus. In their general organization and the structure of the seed coat seeds assigned to Lusitanispermum are similar to the other exotestal seeds described here, and to the two extinct exotestal seeds, Nitaspermum and Tanispermum, however, they are distinguished from these other fossil seeds, except Silutanispermum, by the much thicker mesotesta/ endotesta and in details of the exotestal cells. Among extant angiosperms comparable seeds occur in Illicium and in members of the Nymphaeales. Illicium is, however, distinguished by its strophiole and thinner mesotesta, while seeds of Nymphaeales have an operculum, formed from the inner integument, which has not been seen in the fossil seeds.

\section{Lusitanispermum choffatii gen. et sp. nov.} Text-figs 7-10

Hol otype. Designated here, S174345 (Famalicão sample 025; illustrated here on Text-figs 7a, b, 9a, b).

Plant Fossil Names Registry Number. PFN000097 (for new species).
P a ratypes. Designated here, S105097, S105098, S170239, S174035, S174353, S174467-S174470, S174472, S174474, S174811, S175113 - S175118 (Famalicão sample 025).

R e p o s i t o r y. Palaeobotanical Collections, Department of Palaeobiology, the Swedish Museum of Natural History, Stockholm, Sweden.

Ety mology. In recognition of Léon Paul Choffat (*1849, †1919) for his geological studies of Cretaceous deposits in Portugal.

Ty pe lo c ality. Famalicão, Portugal $\left(39^{\circ} 42^{\prime} 16^{\prime \prime N}\right.$; $\left.8^{\circ} 46^{\prime} 12^{\prime \prime} \mathrm{W}\right)$.

Type stratum and age. Below the Figueira da Foz Formation; Early Cretaceous (late Aptian - early Albian or older).

D i a g n o s is. As for the genus.

D i m e n s i o n s . Length of seeds: $1.7-2.8 \mathrm{~mm}$; width of seeds: $0.8-1.9 \mathrm{~mm}$.

Other material. S175046 (Vale de Água sample 333).

Description and remarks. The species is based on about 120 isolated seeds of which 12 specimens were studied using SRXTM (S105097, S105098, S170239, S174035, S174345, S174353, S174467 - S174470, S174472, $\mathrm{S} 174474)$. There is no information on the fruits in which the seeds were borne. The seeds are small, anatropous, bitegmic and exotestal with bilateral symmetry. They are elliptic in lateral view (Text-figs 7a, c, 8a-e) and elliptical to circular in transverse section (Text-figs 9d, 10e). The seed surface is smooth with a jigsaw puzzle-shaped pattern formed from the slightly raised undulate anticlinal walls of the exotesta cells (Text-fig. 8g). The seeds vary considerably in size and shape and they may belong to more than one natural species. However, there are transitional forms between the smaller more narrow type (Text-fig. 8a-c) and the larger more rounded type (Text-figs $7 \mathrm{a}-\mathrm{c}, 8 \mathrm{~d}$, e) and all specimens are therefore included here in the same species.

The micropyle and hilum are very close together at the seed apex (Text-figs 8b, 10a, d). The hilum is rounded triangular in outline without a hilar rim (Text-fig. 8f). The course of the raphe is not seen on the seed surface. The micropyle is formed from the inner integument and marked externally by a transverse slit in the testa (Text-figs $8 \mathrm{f}, 10 \mathrm{~d}$ ).

The seed coat is composed of a thick exotesta, a thick mesotesta/endotesta, and a thin tegmen. The exotesta consists of a single layer of tall, columnar sclerenchyma cells. In the bulging areas close to the hilum the exotestal cells are up to about $180 \mu \mathrm{m}$ tall (Text-figs 9a-d, 10a, c, e), but are about 95 $\mu \mathrm{m}$ tall laterally and on the antiraphal sides of the seed. These exotesta cells become gradually shorter towards the micropylar slit and in the micropylar region (Text-fig. 10a, b). They have slightly raised anticlinal walls and towards the outside (Textfig. 8g) and inside (Text-fig. 7d) the cells of the exotesta are strongly undulate forming stellate-undulate facets and a jigsaw puzzle-like pattern with rounded, undivided lobes.

In the bulging portion of the seed coat around the micropylar area the cells of exotesta have slightly thinner walls 

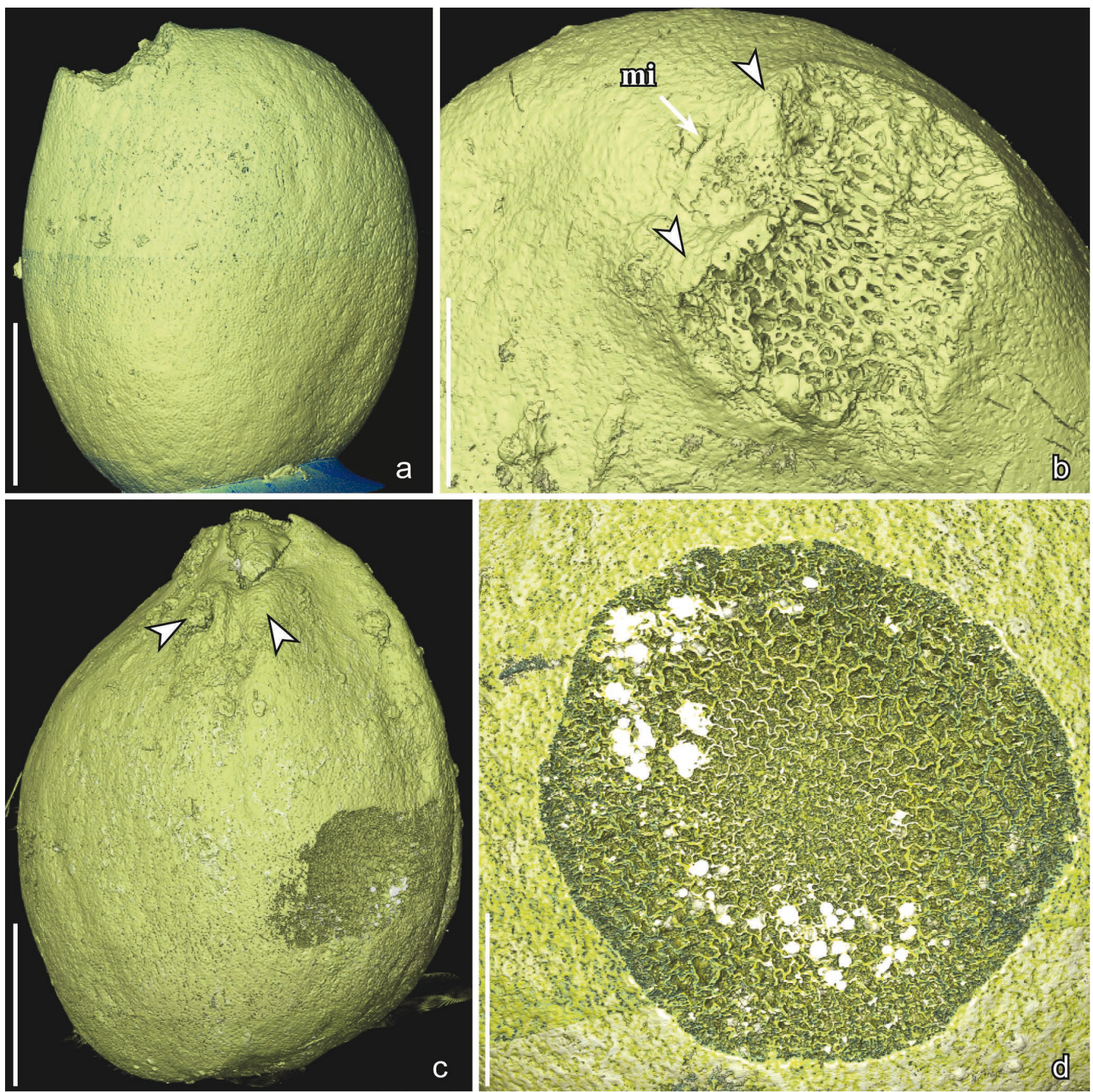

Text-fig. 7. Lusitanispermum choffatii gen. et sp. nov. seeds from the Early Cretaceous Famalicão locality (sample 025), Portugal; Synchrotron radiation X-ray tomographic microscopy (SRXTM, volume renderings). a) Holotype; seed in lateral view showing seed shape; note that the seed is broken near the lower surface of the hilum (S174345). b) Oblique apical view of micropylar-hilar region of holotype showing slightly ruptured micropylar slit (mi) in the outer integument and two bulging and abraded areas (arrow heads) close to hilum. c) Seed in oblique lateral-raphal view showing the two bulging structures (arrow heads) immediately adjacent to the lower edge of the hilum (S174472). d) Tangential, longitudinal cut (cut at yz0131) through the seed coat of seed in (7c) showing the undulate anticlinal cell walls of the exotesta cells that are thickest towards the outside and thinner towards the inside. Scale bars $=500 \mu \mathrm{m}(\mathrm{a}-\mathrm{c}) ; 250 \mu \mathrm{m}(\mathrm{d})$.

(Text-fig. 9c) and this part of the seed is sometimes abraded or collapsed. Also in this part of the seed the cells of the exotesta have straight anticlinal walls and polygonal facets (Text-fig. $8 \mathrm{f})$. The mesotesta/endotesta consists of at least three layers of large parenchyma cells (Text-figs 9a, b, d, 10e), most prominent below the bulging hilar zone (Text-fig. 9b). The tegmen is thin over most of the seed, but thicker towards the micropyle.

Nutritive tissue is well preserved in most specimens studied using SRXTM and in seven specimens (S170239, S174345,
S174468, S174469, S174470, S174472, S174474) a complete or almost complete embryo was observed (Text-figs 9a, b, 10f). In all cases the embryo is tiny, about $110 \mu \mathrm{m}$ long and $180 \mu \mathrm{m}$ broad, with two rudimentary cotyledons (Text-figs $9 \mathrm{~b}, 10 \mathrm{f}$ ), and an embryo to seed ratio of about 0.016 . The cells of the embryo are much smaller than those of the surrounding nutritive tissue and each cell has a dense central structure, which we interpret as the remains of a nucleus (Text-figs 9b, 10f). The nutritive tissue is cellular consisting of isodiametric 

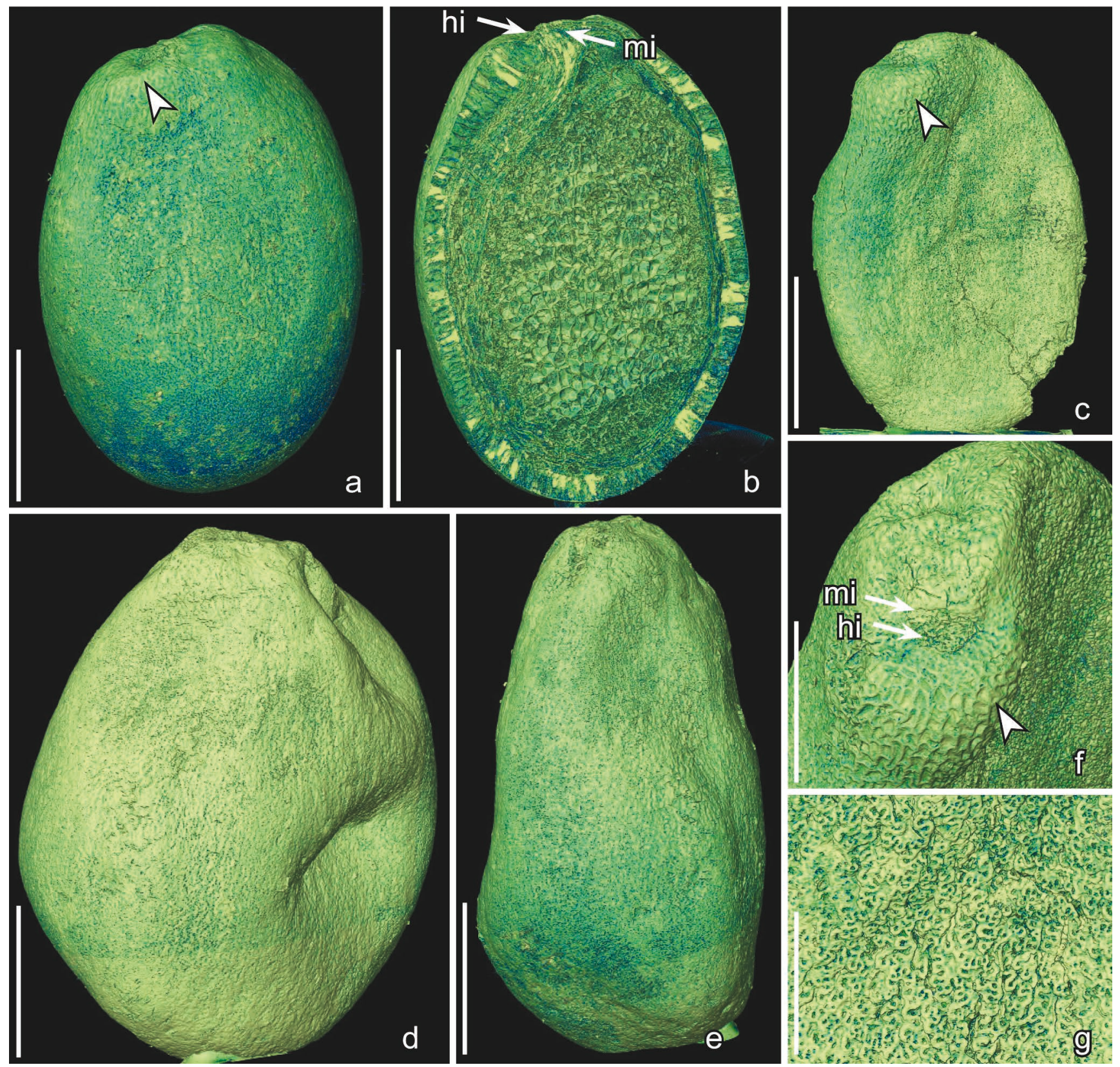

Text-fig. 8. Lusitanispermum choffatii gen. et sp. nov. seeds from the Early Cretaceous Famalicão locality (sample 025) (a, b, d, e), and the Vale de Água locality (sample 333) (c, f, g), Portugal; Synchrotron radiation X-ray tomographic microscopy (SRXTM, volume renderings). a) Smaller seed in lateral view showing the bulging region (arrow head) close to hilum (S174467). b) Cut volume rending (cut at yz1032) of seed in (8a) showing the expanded cells of exotesta immediately adjacent to the lower edge of the hilum (hi), micropyle (mi) and the well preserved nutritive tissue. c) Small seed in lateral view showing the bulging exotesta (arrow head) close to hilum (S175046). d, e) Larger seed in lateral (d) and raphal (e) view (S174035). f) Detail of seed in (8c) showing the micropylar slit (mi) above the hilum (hi) and bulging exotestal tissue (arrow head) in which the walls of the exotestal cells have straight anticlinal walls. g) Surface of seed in (8c) showing the raised undulate anticlinal walls of the exotestal cells. Scale bars = $500 \mu \mathrm{m}$ (a-e); $250 \mu \mathrm{m}$ (f); $125 \mu \mathrm{m}$ (g).

and thin-walled cells, about $40 \mu \mathrm{m}$ in diameter, with thin, straight or slightly undulate cell walls (Text-figs $9 \mathrm{a}-\mathrm{d}, 10 \mathrm{~b}, \mathrm{c}$, e). In most specimens the cells of the nutritive tissue are filled with small granular bodies that we interpret as the remains of protein or lipid bodies (Text-figs 9b, d, 10c, d, f). The cells are rarely completely empty (Text-fig. 10a, b, e).

\section{Genus Silutanispermum gen. nov.}

Ty p e. Designated here, Silutanispermum kvacekiorum gen. et sp. nov.
Plant Fossil Names Registry Number. PFN000098 (for new genus).

Etymology. Silutanispermum is an anagram of Lusitanispermum described above to indicate the similarity of the seeds of the two fossil genera.

D i a g o s is. Isolated seeds occurring singly. Seeds small, anatropous, bitegmic and exotestal. Seeds bilaterally symmetrical with dorsiventral plane of symmetry. Seed surface smooth without longitudinal ridges. Raphe indistinct 

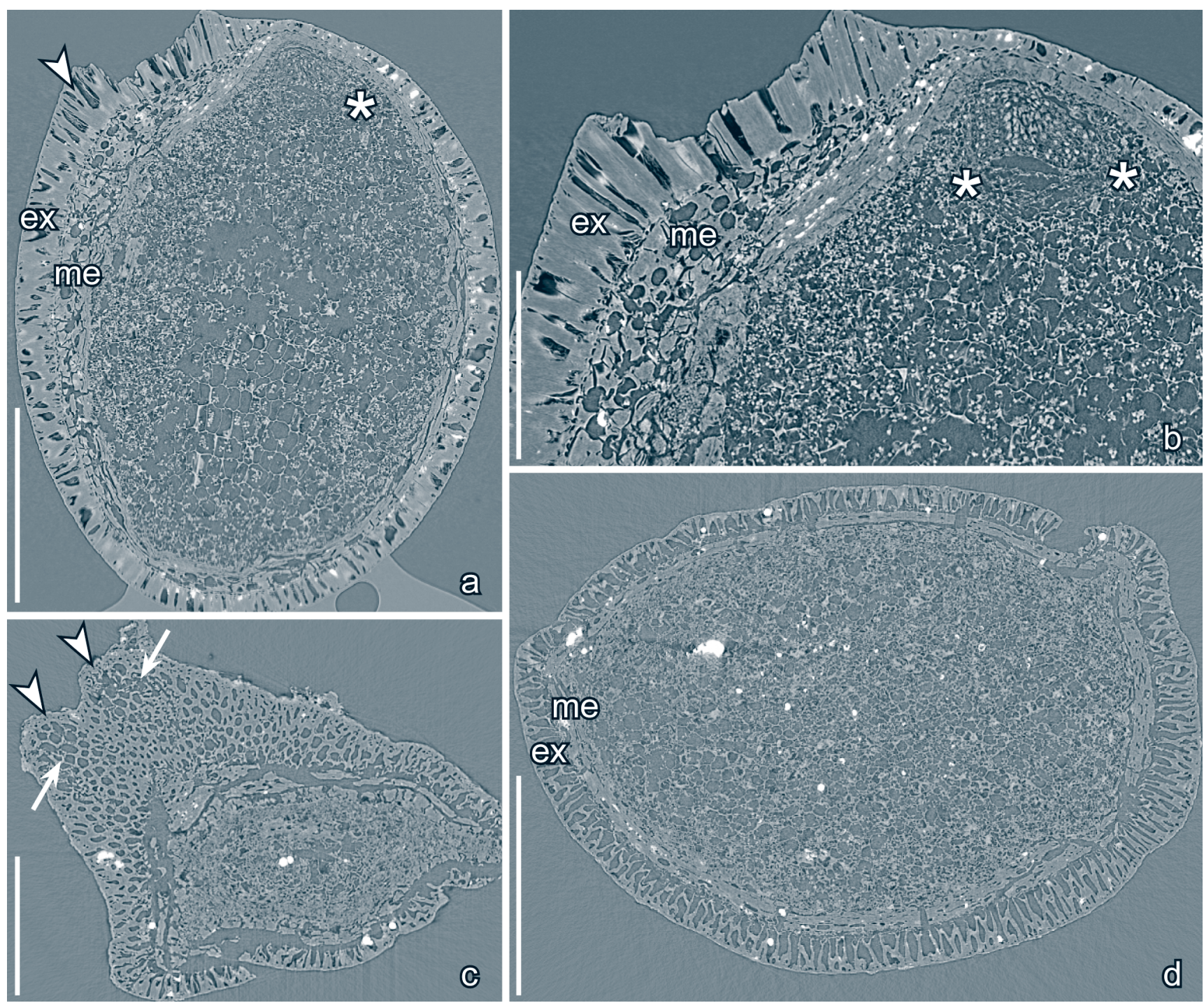

Text-fig. 9. Lusitanispermum choffatii gen. et sp. nov. seeds from the Early Cretaceous Famalicão locality (sample 025), Portugal; Synchrotron radiation X-ray tomographic microscopy (SRXTM, orthoslices). a) Longitudinal orthoslice (yz0769) through the median plane of the seed (S174345) showing expanded exotestal cells (ex, arrow head) in the hilar region and well-preserved cellular nutritive tissue with an embedded tiny embryo (asterisk markes the margin of the embryo); note well-developed mesotesta (me) on the raphal side of seed. b) Longitudinal orthoslice (yz0750) in the median plane showing detail of micropylar part of seed with well-preserved exotesta (ex) and mesotesta (me) and tiny embryo with two rudimentary cotyledons (asterisks mark the margin of the cotyledons); note numerous granular bodies in the cellular nutritive tissue that are probably the remains of protein and lipid bodies. c) Transverse orthoslice (xy0311) through seed below hilum showing the bulging exotesta (arrow heads) (S174472); note that the exotestal cells in this region have thinner walls (arrows). d) Transverse orthoslice (xy0900) through the middle of a seed showing the uneven thickening of the anticlinal walls of the exotestal cells (ex), which are thicker towards the outside and very thin towards the inside; note also mesotesta (me) and the well-preserved cellular nutritive tissue (S174472). Scale bars $=500 \mu \mathrm{m}(\mathrm{a}, \mathrm{d}) ; 250 \mu \mathrm{m}(\mathrm{b}, \mathrm{c})$.

externally. Hilum and micropyle separated by a narrow zone of testal sclerenchyma. Hilar scar small, triangular without a rim. Micropyle formed by the inner integument (tegmen) and marked on the seed surface by a transverse, slightly wavy slit through the outer integument (testa) adjacent to hilar scar. Testa formed from an outer layer (exotesta) of palisade-shaped sclerenchyma cells and an inner thick layer of large parenchyma cells (mesotesta/endotesta), that is particularly well-developed close to hilum. Palisade-shaped cells of exotesta with unevenly thickened walls that are thick towards the outside, slightly thinner towards the inside, but with an almost straight lumen. Anticlinal walls of palisadeshaped sclerenchyma strongly undulate towards the inside and towards the outside, resulting in stellate-undulate facets and a jigsaw puzzle-like pattern on the seed surface except over the raphe where the cell walls are straight and facets polygonal. Tegmen thin. Embryo tiny with two rudimentary cotyledons.

Comments on the genus. Seeds assigned to Silutanispermum are similar to those of Lusitanispermum, and are distinguished from seeds of Gastonispermum, Pazlia, Pazliopsis and Reyispermum by their well-developed mesotesta. Silutanispermum seeds are distinguished from those of Lusitanispermum by the shape of the micropyle. In Silutanispermum the micropyle is lined by tall testal cells and 
is seen on the surface as a prominent, slightly wavy, slit. In Lusitanispermum the micropyle is less distinct. There are also differences in details of the seed coat, including especially the absence of any significant expansion in the thickness of the exotesta below the hilum in Silutanispermum.

\section{Silutanispermum kvacekiorum gen. et sp. nov.} Text-figs 11-12

Holotype. Designated here, S170238 (Famalicão sample 025; illustrated here on Text-figs 11a, b, d, e, 12a, b).

Plant Fossil Names Registry Number. PFN000099 (for new species).

P a r a ty p es. Designated here, S174352 (Famalicão sample 025).

R e p o s i t o r y. Palaeobotanical Collections, Department of Palaeobiology, the Swedish Museum of Natural History, Stockholm, Sweden.

E t y m o lo g y. In recognition of Zlatko and Jiř́ Kvaček for their many contributions to angiosperm palaeobotany.

Type 1 o cality. Famalicão, Portugal $\left(39^{\circ} 42^{\prime} 16^{\prime \prime} \mathrm{N}\right.$; $\left.8^{\circ} 46^{\prime} 12^{\prime \prime} \mathrm{W}\right)$.

Type stratum and age. Below the Figueira da Foz Formation; Early Cretaceous (late Aptian - early Albian or older).

Di a g n o s is. As for the genus.

D i m e n s i o n s . Length of seeds: 1.6-2.0 mm; width of seeds: $1.2-1.9 \mathrm{~mm}$.

Description and remarks. The species is based on two isolated seeds that were studied using SRXTM (S170238, 174352). There is no information on the fruits in which the seeds were borne. The seeds are small, anatropous, bitegmic and exotestal with bilateral symmetry. They are elliptic in lateral view (Text-fig. 11a-c) and elliptical to circular in transverse section (Text-fig. 12c, d). The seed surface is smooth with a jigsaw puzzle-shaped pattern formed from the slightly raised undulate anticlinal walls of the exotesta cells.

The micropyle and hilum are very close together and slightly displaced towards the raphal side of the seed (Textfig. $11 \mathrm{a}-\mathrm{d})$. The hilum is rounded triangular in outline without a hilar rim (Text-fig. 11d). The course of the raphe is seen on the seed surface as a slightly raised ridge that is also distinctive in its transversely aligned cells. The micropyle is formed from the inner integument and is marked on the outside by a transverse, slightly undulate slit in the testa (Text-figs 11d, 12b). Internally the micropylar slit is lined by tall cells of the exotesta (Text-fig. 12a, b) and there is a tendency towards a Y-shaped branching internally.

The seed coat is composed of a thick exotesta, a thick mesotesta/endotesta, and a thin tegmen. The exotesta consists of a single layer of tall, columnar sclerenchyma cells that are about $65 \mu \mathrm{m}$ tall over most of the seed (Textfig. $12 \mathrm{a}, \mathrm{c}-\mathrm{e}$ ) but taper out in the micropylar region (Text-fig. 12a). The anticlinal walls of the exotestal cells are thickened, and of almost even thickness from the outside to the inside, resulting in an almost straight lumen (Text-fig. 12c-e). The anticlinal walls are strongly undulate towards the outside and the inside forming stellate-undulate facets and a jigsaw puzzle-like pattern with rounded, undivided lobes on the seed surface; except over the raphe where the cell walls are straight and the facets are polygonal. The mesotesta/ endotesta is as thick as the exotesta, about $65 \mu \mathrm{m}$ over most of the seed, and consists of up to five layers of large rectangular, tangentially elongated parenchyma cells, (Textfig. 12c-e). The mesotesta/endotesta is thickest around the raphe and close to the hilar region it is up to about $180 \mu \mathrm{m}$ thick (Text-fig. 12c). The tegmen is thin.

Nutritive tissue is well preserved in one of the specimens studied using SRXTM (S174352). It is cellular, consisting of isodiametric cells, about $55 \mu \mathrm{m}$ in diameter, with thin, straight, cell walls (Text-fig. 12d).

\section{Discussion}

\section{Distinguishing features of Gastonispermum, Pazlia, Pazliopsis, Reyispermum, Lusitanispermum and Silutanispermum}

The fossil seeds described here are part of a diverse complex of anatropous, bitegmic and exotestal seeds, with palisade-shaped exotestal cells, that are common in Early Cretaceous mesofossil floras from Portugal. The analyses presented here are the first detailed studies of these seeds. The total diversity of these kinds of exotestal seeds in the Portuguese floras that we have studied is currently uncertain, but the six genera described here represent only a quarter or less of the more than 20 extinct genera that are present. The seeds vary in surface ornamentation and include a range of spiny, ribbed and smooth types.

In this study we have focused on a selection of seeds with an almost smooth surface and a jigsaw puzzle-shaped surface pattern created by the strongly undulate and slightly raised anticlinal walls of the exotestal cells. Six new genera are described, Gastonispermum, Pazlia, Pazliopsis, Reyispermum, Lusitanispermum and Silutanispermum, based on differences in seed coat structure and details in the hilarmicropylar region. Pazliopsis is based on small one-seeded fruits/fruitlets as well as isolated seeds, while the other five genera are known only from isolated seeds. In all cases the isolated seeds usually have smooth faces without impressions of neighboring seeds. We therefore infer that all seeds described were borne in one-seeded fruits/fruitlets. This inference needs to be tested as further specimens are recovered.

In all six genera the micropyle is formed from the inner integument, and is seen on the seed surface as a more or less distinct slit in the exotesta. This slit is Y-shaped in Gastonispermum, but transversely elongate in Pazlia, Pazliopsis, Reyispermum, Lusitanispermum and Silutanispermum. The hilar scar is small, and circular or triangular, in Gastonispermum, Reyispermum, Lusitanispermum and Silutanispermum and the hilarmicropylar profile is rounded to pointed. In contrast, in seeds of Pazlia and Pazliopsis the hilar scar is larger and more prominent, and the hilar-micropylar profile is truncate.

Seeds of Pazlia and Pazliopsis are further distinguished from seeds of the other four genera by the prominent and 
extended sclerenchyma tissue that occurs beneath the hilar scar. Seeds of Lusitanispermum and Silutanispermum are distinguished from seeds of the other four genera by their well-developed mesotesta, which is especially well developed in Silutanispermum. Lusitanispermum is distinct in the marked expansion of the exotesta close to hilum.

Remains of cellular nutritive tissue have been observed inside the seed coat in all six taxa. This nutritive tissue consists of small equiaxial cells with thin cell walls. The cells may be empty, but in many cases are filled with small granular bodies, which we interpret as the remains of protein or lipid bodies. The nutritive tissue is particularly well-preserved in seeds of Lusitanisperm and Silutanispermum and we interpret it as the remains of endosperm, which would be typical for most angiosperms. In Pazliopsis the endosperm immediately surrounding the embryo is well-preserved and appears different from the bulk of the nutritive tissue. However, cellular details in the tissues surrounding the embryo are not sufficiently clear in any of the seeds to definitively confirm the presence of both endosperm and perisperm. In seeds of extant Nymphaeales, where the nutritive tissue is mainly perisperm, the endosperm forms a narrow zone immediately surrounding the embryo and it is distinctly delimited from the perisperm by larger cells (e.g. Floyd and Friedman 2000, Friedman and Bachelier 2013). Such a distinct delimitation has not so far observed in the fossil seeds.

Well-preserved embryos with two rudimentary cotyledons are present in specimens of Gastonispermum, Pazliopsis and Lusitanispermum. In all three taxa the embryo is tiny, as is also inferred for Reyispermum and Silutanispermum by the small empty space that indicates embryo's former position. In Gastonispermum and Pazliopsis the embryo : seed ratio is about 0.02 , but it is even smaller (0.016) in Lusitanispermum.

Seed coat structure in the new taxa from Portugal is very similar to that in fossil seeds assigned to Nitaspermum and Tanispermum from the Early Cretaceous Puddledock and Kenilworth mesofossil floras from eastern North America. A total of 10 species of exotestal seeds were included in these two genera, all with strongly undulate anticlinal walls of the exotestal cells that result in a jigsaw puzzle-shaped surface ornamentation (Friis et al. 2018c, b). However, Tanispermum differs from all the seeds described here, as well as seeds of Nitaspermum, in its hemianatropous- hemiorthotropous organization and the apparent presence of a small operculum.

The seeds described here from Portugal are more similar to those from the Early Cretaceous of North America described as Nitaspermum. In both cases the seeds are anatropous and have the hilum and micropyle separated by a zone of well-developed testal tissue. In Nitaspermum this testal tissue is expanded in the region between hilum and micropyle, but is poorly developed on the antiraphal side of the micropyle. The Portuguese seeds differ in that this zone of well-developed testal tissue completely surrounds the micropylar slit. The distinct hilar rim seen in most species of Nitaspermum is also missing from the fossil seeds from Portugal described here. Nitaspermum seeds have a tiny embryo, as in Gastonispermum, Pazliopsis and Lusitanispermum, although it is not as well preserved.

A summary of seed characters in other exotestal seeds previously described from the Cretaceous was provided in the discussion of Nitaspermum (Friis et al. 2018c). Notably, the two Early Cretaceous taxa, Anacostia E.M.FriIs, P.R.Crane et K.R.Pedersen and Couperites K.R.Pedersen, P.R.Crane, A.N.Drinnan et E.M.Fris are distinct from the seeds described here. In both genera the exotesta is composed of cuboidal cells with straight anticlinal walls towards the outside of the seed, and in Anacostia these cells are distinctly crystalliferous (Friis et al. 2018c). Similarly, the small exotestal seeds from the Early Cretaceous of Japan assigned to Trimeniaceae, differ from the Portuguese and North American fossils in having an exostesta consisting of multiple layers of equiaxial sclerenchyma cells that lack undulating anticlinal walls (Yamada et al. 2008).

The Late Cretaceous seeds of Illiciospermum are more similar to Nitaspermum and to the Portuguese seeds, especially in details of the seed coat. However, Illiciospermum has a raised area between hilum and micropyle (strophiole), similar to that in extant Illicium, which is not known in the six genera from Portugal. A strophiole-like structure occurs in the seeds of Reyispermum, but it is positioned below, rather than between, the micropyle and hilum.

\section{Systematic assignment of the fossil seeds \\ The exotestal and bitegmic organization of seeds of Gastonispermum, Pazlia, Pazliopsis, Reyispermum,}

Text-fig. 10. Lusitanispermum choffatii gen. et sp. nov. seeds from the Early Cretaceous Famalicão locality (sample 025), Portugal; Synchrotron radiation X-ray tomographic microscopy (SRXTM, orthoslices). a) Longitudinal orthoslice (yz1020) through the median plane of seed in the micropylar region showing details of taller expanded cells of the exotesta (arrow head), hilum (hi) and micropyle (mi); elongated cells from hilum mark the apical part of raphe well; note the well preserved cellular nutritive tissue with thin cell walls and no cell contents (S174467). b) Longitudinal orthoslice (xz0778) of seed through the micropylar region perpendicular to the median plane of the seed showing the micropylar slit $(\mathrm{mi})$ in the exotesta and the well-preserved nutritive tissue comprised of cells with no contents (S174467). c) Longitudinal orthoslice (yz0945) through the median plane of the seed in the micropylar region showing the expanded exotesta immediately adjacent to the lower edge of the hilum (arrow head), hilum (hi), micropyle (mi) and mesotesta (me); note the well-preserved nutritive tissue with numerous granular bodies that are probably the remains of protein and lipid bodies $(\mathbf{S 1 7 4 4 6 8 )}$. d) Longitudinal orthoslice (zx0873) through the middle of a seed perpendicular to the median plane showing details of the micropylar region with micropylar slit (mi) in the exotesta and well-preserved nutritive tissue (S174468). e) Transverse orthoslice (xy1762) showing seed coat with well-developed exotesta and mesotesta (me) as well as nutritive tissue (S174035). f) Longitudinal orthoslice (yz1335) of seed through the micropylar region perpendicular to the median plane showing tiny embryo with two rudimentary cotyledons (asterisks mark the margin of the cotyledons) and well-preserved cellular nutritive tissue; the embryo has smaller cells than the surrounding nutritive tissue and the cells of the embryo each contain a small central body interpreted as fossilized remains of nuclei while the cells of the nutritive tissue enclose fossilized remains of nutritive bodies (S174468). Scale bars $=250 \mu \mathrm{m}$ (a-e); $125 \mu \mathrm{m}$ (f). 

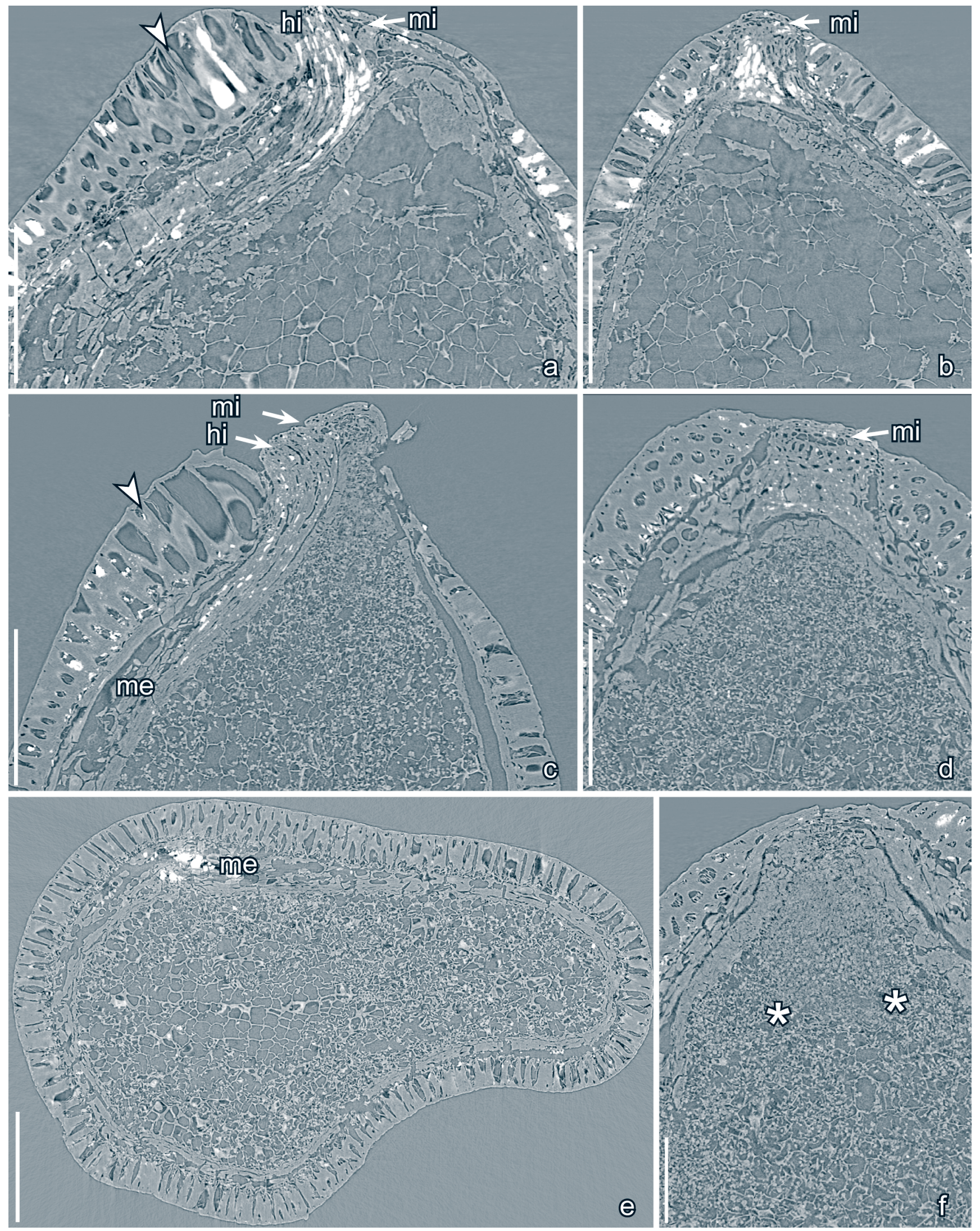

Lusitanispermum and Silutanispermum, combined with the characteristic single layer of exotestal sclerenchyma cells with undulate anticlinal walls, as well as details of the hilar and micropylar region, strongly suggest a phylogenetic position for the fossils near extant Austrobaileyales and Nymphaeales, as discussed in detail for Nitaspermum and
Tanispermum (Friis et al. 2018b, c). The tiny embryo with two rudimentary cotyledons observed in the Gastonispermum, Pazliopsis and Lusitanispermum seeds is also consistent with this conclusion.

Austrobaileyales and Nymphaeales, together with Amborellaceae, constitute the three earliest diverging 

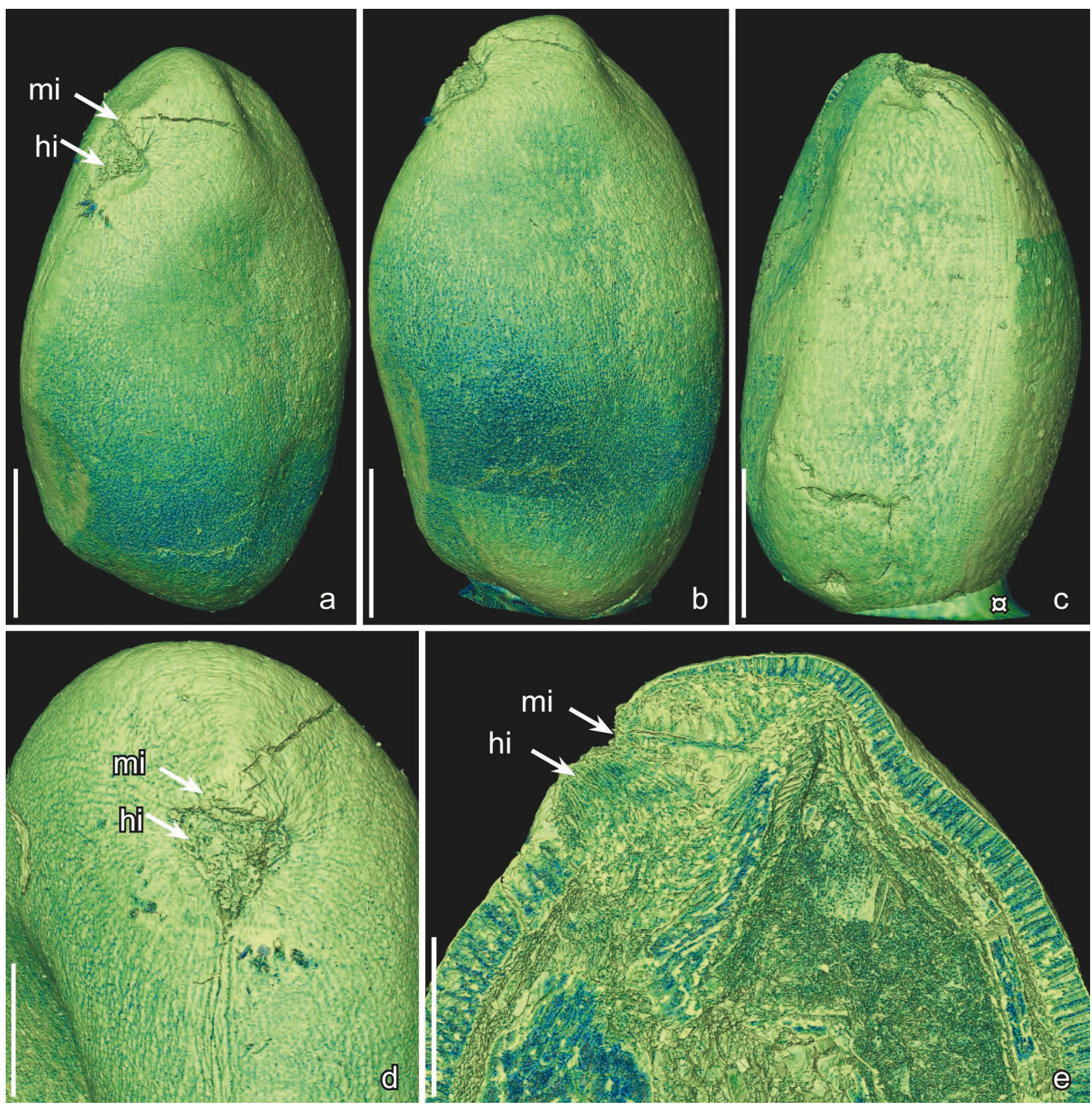

Text-fig. 11. Silutanispermum kvacekiorum gen. et sp. nov. seeds from the Early Cretaceous Famalicão locality (sample 025), Portugal; Synchrotron radiation X-ray tomographic microscopy (SRXTM, volume renderings). a, b) Holotype (S170238), seed in oblique (a) and lateral (b) view showing large triangular hilar scar (hi) and transverse micropylar slit (mi). c) Oblique view of seed showing slightly raised raphal area (S174352); remains of mounting media (a). d) Details of holotype showing triangular hilum (hi) and transverse micropylar slit in the exotesta (mi). e) Cut volume rendering of holotype (cut at yz1170) through the median plane showing hilum (hi) and micropylar slit (mi) lined by radially expanded exotestal cells. Scale bars $=500 \mu \mathrm{m}(\mathrm{a}-\mathrm{c}) ; 250 \mu \mathrm{m}(\mathrm{d}, \mathrm{e})$.

lineages under current hypotheses of the phylogenetic relationships of extant angiosperms. Strikingly, today all three lineages are remarkably species-poor (Magallon and Sanderson 2002) and the full diversity of these lineages over time remains obscure. Seeds of Amborella are unique. They are clearly distinguished from the fossil seeds described here, and seeds of all other Austrobaileyales and Nymphaeales, by their very thin, endotegmic-exotestal seed coat (Tobe et al. 2000). Extant Austrobaileyales include four families (Austrobaileyaceae, Trimeniaceae, Illiciaceae, Schisandraceae), while extant Nymphaeales include three
(Hydatellaceae, Cabombaceae, Nymphaeaceae). Among these seven families, exotestal seeds with palisadeshaped sclerenchyma cells that have strongly undulate anticlinal walls, similar to those of the fossil seeds, occur in Illicium (Illiciaceae), Brasenia Schreb. and Cabomba Aubl. (Cabombaceae), as well as most members of the Nymphaeaceae (Barcleya SalisB., Nymphaea L., Ondinea Hartog, Victoria Lindl.) (Collinson 1980, Oh et al. 2003, Takahashi et al. 2007).

Seeds of Illicium and Nymphaeaceae are especially similar to the Early Cretaceous fossil seeds from Portugal 

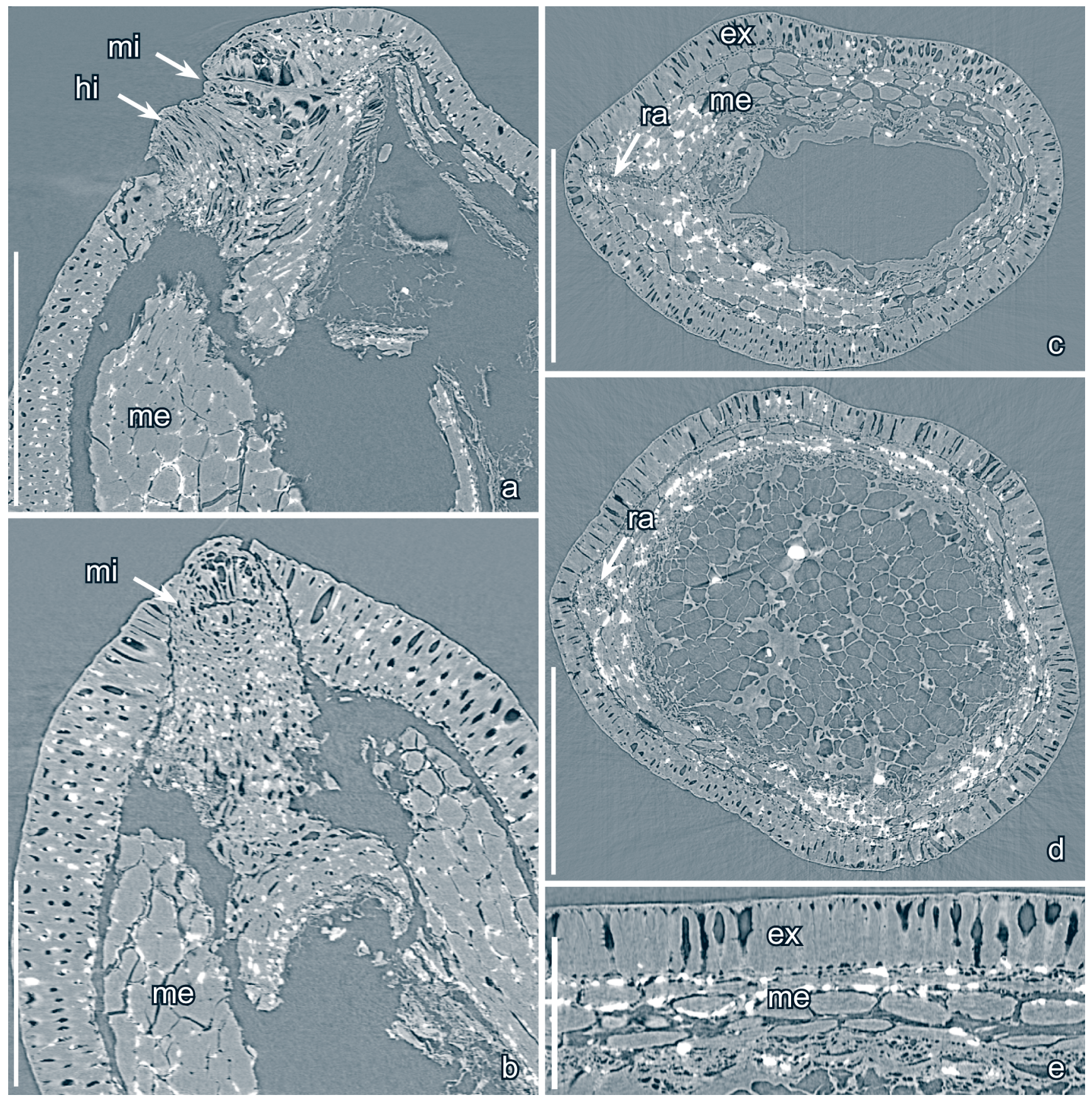

Text-fig. 12. Silutanispermum kvacekiorum gen. et sp. nov. seeds from the Early Cretaceous Famalicão locality (sample 025), Portugal; Synchrotron radiation X-ray tomographic microscopy (SRXTM, orthoslices). a) Longitudinal orthoslice (yz1170) through the median plane of the seed (S170238) in the micropylar region showing exotestal cells lining the micropylar slit (mi) and hilum (hi); note the well-preserved mesotestal cells (me). b) Longitudinal orthoslice (xz0805) of seed perpendicular to the median plane through the micropylar region showing the transverse micropylar slit (mi) lined by radiating exotestal cells; note abundant mesotestal cells (me). c) Transverse orthoslice (xy0768) through seed below hilum and micropyle showing exotesta (ex) and mesotesta (me) that is strongly developed along the raphe (ra) (S174352). d) Transverse orthoslice (xy2113) through middle of the seed showing well-preserved cellular nutritive tissue with empty cells; note that the raphe (ra) is enclosed in mesotestal tissue (S174352). e) Longitudinal orthoslice (yz0970) through seed coat showing exotesta (ex) of tall palisade-shaped cells and thick mesotesta (me) of low cells (S174352). Scale bars = 500 $\mu \mathrm{m}$ (a, c, d); $250 \mu \mathrm{m}$ (b); $125 \mu \mathrm{m}$ (e).

in having a zone of testal tissue between the micropyle and hilum, while in Cabomba and Brasenia micropyle and hilum occur next to each other and are not separated by testal tissue (Yamada et al. 2001, Oh et al. 2003). In Illicium the zone of testal tissue separating the micropyle and hilum typically forms a broad and prominently raised structure, the so-called strophile (Oh et al. 2003). This is unlike the condition in any of the fossil seeds, which is more similar to the situation in the Nymphaeaceae, except that seeds of Nymphaeaceae have an operculum formed by the inner integument, which we have not observed in the fossils.

In both Austrobaileyales and Nymphaeales the embryo is tiny with rudimentary cotyledons and the nutritive tissue is cellular. In Austrobaileyales the nutritive tissue is 
mainly endosperm, as in most other angiosperms, while in Nymphaeales it is mostly perisperm with only a narrow zone of endosperm surrounding the embryo (Floyd and Friedman 2001, Friedman et al. 2012, Friedman and Bachelier 2013, Losada et al. 2017). Pazliopsis offers the most potential to distinguish endosperm from perisperm in our fossil material. The cells of the presumed endosperm close to the embryo are larger in extant Nymphaeales than the cells of the remaining nutritive tissue, but so far we have seen no clear separation between putative perisperm and putative endosperm in our fossil material. Pursuing the possibility of distinguishing endosperm from perisperm in Pazliopsis will require betterpreserved material.

\section{Conclusion}

The six new species of fossil seeds described here from Early Cretaceous mesofloras from Portugal, together with the 10 species of Nitaspermum and Tanispermum described previously from the Early Cretaceous of eastern North America, provide a new glimpse into the rich extinct diversity that existed around 110-120 million years ago during the earliest phases of angiosperm evolution. They provide compelling evidence of a great variety of extinct taxa related to extant Austrobaileyales and Nymphaeales, underlining the extent to which the relatively few extant taxa in these lineages are probably unrepresentative of the diversity of plants that existed in these lineages in the past.

The magnitude of extensive extinction in the history of early angiosperm lineages is particularly striking in the case of Nymphaeales where in addition to the extinct diversity related to the group from the Early Cretaceous there is also an extensive fossil record through the Cenozoic that provides substantial evidence of later diversification and extinction, including especially of a rich variety of ancient forms related to Cabombaceae (Brasenia and Cabomba) (Miki 1960, Dorofeev 1974, Collinson 1980, Friis et al. 2011 2017). In this context, the nine living genera of extant Nymphaeales are relictual only in the sense that they are the last living representatives of lineages that are very ancient, but at the same time they are mainly expressions of much more recent diversification, which itself has resulted in extraordinary structural variety. For example, some modern concepts of the genus Nymphaea imply that it should include the likely wind-pollinated genus Ondinea, as well as forms that range from the tiny-flowered Nymphaea thermarum EB.FISCH. to species such as Euryale ferox SALISB. and Victoria amazonica (Poepr.) J.C.Sowerby that have massive floating leaves and gigantic flowers (Löhne et al. 2007).

The fossil seeds described here, and also previously (Friis et al. 2018b, c), provide strong evidence of extensive speciation and pervasive extinction at a very early stage of angiosperm diversification. This extinct diversity is only just beginning to emerge from obscurity, but deep knowledge of these ancient plants is essential for meaningful interpretations of patterns and processes during the earliest phases of angiosperm evolution. Many features of early angiosperms that are of great interest for interpreting early patterns and processes in angiosperm evolution, for example their genomes and aspects of their reproductive biology, can only be inferred from studies of living plants. However, in light of increasing evidence of large-scale extinction among the earliest angiosperms, and also through the ensuing 100 million years, prudence dictates that the results of extrapolations based solely on living taxa should be treated with an abundance of caution.

\section{Acknowledgements}

We thank the Paul Scherrer Institut, Villigen, Switzerland, for provision of synchrotron radiation beamtime at the TOMCAT beamline X02DA of the Swiss Light Source. We are grateful to Federica Marone for her help at the beamline (projects 20110963, 20130185, 20141047, 20160140 and 20171476) and Anna Lindström for help with the SRXTM analyses. We also thank Margaret Collinson and an anonymous reviewer from helpful comments. Support for this research was also obtained from the Swedish Research Council (2014-5228).

\section{References}

Collinson, M. E. (1980): Recent and Tertiary seeds of the Nymphaeaceae sensu lato with a revision of Brasenia ovula (Brong.) Reid and Chandler. - Annals of Botany, 46: 603-632.

https://doi.org/10.1093/oxfordjournals.aob.a085958

Dinis, J. L., Rey, J., Cunha, P. P., Callapez, P., Pena Dos Reis, R. (2008): Stratigraphy and allogenic controls of the western Portugal Cretaceous: an updated synthesis. Cretaceous Research, 29: 772-780. https://doi.org/10.1016/j.cretres.2008.05.027

Dorofeev, P. I. (1974): Nymphaeales. - In: Takhtajan, A. (ed.), Magnoliophyta fossila URSS. Nauka, Leningrad, pp. 52-85. (in Russian)

Eriksson, O., Friis, E. M., Pedersen, K. R., Crane, P. R. (2000): Seed size and dispersal systems of Early Cretaceous angiosperms from Famalicão, Portugal. - International Journal of Plant Sciences, 161: 319-329. https://doi.org/10.1086/314248

Floyd, S. K., Friedman, W. E. (2000): Evolution of endosperm developmental patterns among basal flowering plants. - International Journal of Plant Sciences, 161: S57-S81. https://doi.org/10.1086/317579

Floyd, S. K., Friedman, W. E. (2001): Developmental evolution of endosperm in basal angiosperms: Evidence from Amborella (Amborellaceae), Nuphar (Nymphaeaceae), and Illicium (Illiciaceae). - Plant Systematics and Evolution, 228: 153-169. https://doi.org/10.1007/s006060170026

Friedman, W. E., Bachelier, J. B. (2013): Seed development in Trimenia (Trimeniaceae) and its bearing on the evolution of embryo-nourishing strategies in early flowering plant. - American Journal of Botany, 100: 906-915. https://doi.org/10.3732/ajb.1200632

Friedman, W. E., Bachelier, J. B., Hormaza, J. I. (2012): Embryology in Trithuria submersa (Hydatellaceae) and relationships between embryo, endosperm, and perisperm in 
early-diverging flowering plants. - American Journal of Botany, 99: 1083-1095.

https://doi.org/10.3732/ajb.1200066

Friis, E. M., Crane, P. R., Pedersen, K. R. (1997): Anacostia, a new basal angiosperm from the Early Cretaceous of North America and Portugal with trichotomocolpate/ monocolpate pollen. - Grana, 36: 225-244. https://doi.org/10.1080/00173139709362611

Friis, E. M., Crane, P. R., Pedersen, K. R. (2011): Early flowers and angiosperm evolution. - Cambridge University Press, Cambridge, 596 pp. https://doi.org/10.1017/CBO9780511980206

Friis, E. M., Crane, P. R., Pedersen, K. R. (2018a): Rightcania and Kvacekispermum: Early Cretaceous seeds from eastern North America and Portugal provide further evidence of the early chloranthoid diversification. - Fossil Imprint, 74(1-2): 65-76. https://10.2478/if-2018-0006

Friis, E. M., Crane, P. R., Pedersen, K. R. (2018b): Tanispermum, a new genus of distinctive hemi-orthotropous to hemianatropous angiosperm seeds from the Early Cretaceous of eastern North America. - American Journal of Botany.

Friis, E. M., Crane, P. R., Pedersen, K. R. (2018c): Fossil seeds with affinities to Austrobaileyales and Nymphaeales from the Early Cretaceous (early to middle Albian) of Virginia and Maryland, U.S.A: new evidence for extensive extinction near the base of the angiosperm tree. - In: Krings, M., Harper, C. J., Cúneo, N. R., Rothwell, G. W. (eds), Transformative paleobotany. Academic Press, London, pp. 417-435.

Friis, E. M., Crane, P. R., Pedersen, K. R., Stampanoni, M., Marone, F. (2015a): Exceptional preservation of tiny embryos documents seed dormancy in early angiosperms. Nature, 528: 551-554.

https://doi.org/10.1038/nature16441

Friis, E. M., Grimm, G. W., Mendes, M. M., Pedersen, K. R. (2015b): Canrightiopsis, a new Early Cretaceous fossil with Clavatipollenites-type pollen bridge the gap between extinct Canrightia and extant Chloranthaceae. Grana, 54: 184-212. https://doi.org/10.1080/00173134.2015.1060750

Friis, E. M., Iglesias, A., Reguero, M. A., Mörs, T. (2017): Notonuphar antarctica, an extinct water lily (Nymphaeales) from the Eocene of Antarctica. - Plant Systematics and Evolution, 303: 969-980. https://doi.org/10.1007/s00606-017-1422-y

Friis, E. M., Marone, F., Pedersen, K. R., Crane, P. R., Stampanoni, M. (2014): Three-dimensional visualization of fossil flowers, fruits, seeds and other plant remains using synchrotron radiation X-ray tomographic microscopy (SRXTM): New insights into Cretaceous plant diversity. - Journal of Paleontology, 88: 684-701. https://doi.org/10.1666/13-099

Friis, E. M., Pedersen, K. R. (2011): Canrightia resinifera gen. et sp. nov., a new extinct angiosperm with Retimonocolpites-type pollen from the Early Cretaceous of Portugal: missing link in the eumagnoliid tree? - Grana, 50: 3-29. https://doi.org/10.1080/00173134.2011.559728

Friis, E. M., Pedersen, K. R., Crane, P. R. (1999): Early angiosperm diversification: the diversity of pollen associated with angiosperm reproductive structures in Early Cre- taceous floras from Portugal. - Annals of the Missouri Botanical Garden, 86: 259-296.

https://doi.org/10.2307/2666179

Friis, E. M., Pedersen, K. R., Crane, P. R. (2009): Early Cretaceous mesofossils from Portugal and eastern North America related to the Bennettitales-Erdtmanithecales-Gnetales group. - American Journal of Botany, 96: 252-283. https://doi.org/10.3732/ajb.0800113

Friis, E. M., Pedersen, K. R., Crane, P. R. (2010): Cretaceous diversification of angiosperms in the western part of the Iberian Peninsula. - Review of Palaeobotany and Palynology, 162: 341-361. https://doi.org/10.1016/j.revpalbo.2009.11.009

Frumin, S., Friis, E. M. (1999): Magnoliid reproductive organs from the Cenomanian-Turonian of north-western Kazakhstan: Magnoliaceae and Illiciaceae. - Plant Systematics and Evolution, 216: 265-288. https://doi.org/10.1007/BF01084403

Losada, J. M., Bachelier, J. B., Friedman, W. E. (2017): Prolonged embryogenesis in Austrobaileya scandens (Austrobaileyaceae): its ecological and evolutionary significance. - New Phytologist, 215: 851-864. https://doi.org/10.1111/nph.14621

Löhne, C., Borsch, T., Wiersema, J. H. (2007): Phylogenetic analysis of Nymphaeales using fast-evolving and noncoding chloroplast markers. - Botanical Journal of the Linnean Society, 154: 141-163. https://doi.org/10.1111/j.1095-8339.2007.00659.x

Magallon, S., Sanderson, M. (2002): Relationships among seed plants inferred from highly conserved genes: Sorting conflicting phylogenetic signals among ancient lineages. - American Journal of Botany, 89: 1991-2006. https://doi.org/10.3732/ajb.89.12.1991

Miki, S. (1960): Nymphaeaceous remains in Japan, with new fossil genus Eoeuryale. - Journal of the Institute of Polytechnics, Osaka City University, 11: 63-78.

Oh, I.-C., Denk, T., Friis, E. M. (2003): Evolution of Illicium (Illiciaceae): Mapping morphological characters on the molecular tree. - Plant Systematics and Evolution, 240: 175-209. https://doi.org/10.1007/s00606-003-0022-1

Pedersen, K. R., Crane, P. R., Drinnan, A. N., Friis, E. M. (1991): Fruits from the mid-Cretaceous of North America with pollen grains of the Clavatipollenites type. Grana, 30: 577-590. https://doi.org/10.1080/00173139109427816

Schindelin, J., Arganda-Carreras, I., Frise, E., Kaynig, V., Longair, M., Pietzsch, T., Preibisch, S., Rueden, S., Saalfeld, S., Schmid, B., Tinevez, J.-Y., White, D. J., Hartenstein, V., Eliceiri, K., Tomancak, P., Cardona, A. (2012): Fiji: an open-source platform for biological-image analysis. - Nature methods, 9: 676-682. https://doi.org/10.1038/nmeth.2019

Stampanoni, M., Groso, A., Isenegger, A., Mikuljan, G., Chen, Q., Bertrand, A., Henein, S., Betemps, R., Frommherz, U., Bohler, P., Meister, D., Lange, M., Abela, R. (2006): Trends in synchrotron-based tomographic imaging: the SLS experience. - In: Bonse, U. (ed.), Developments in X-Ray Tomography V. Proceedings of SPIE-The International Society for Optical Engineering, 6318: 14 pp. https://doi.org/10.1117/12.679497 
Takahashi, M., Crane, P. R., Friis, E. M. (2007): Fossil seeds of Nymphaeales from the Tamayama Formation (Futaba Group), Upper Cretaceous (Early Santonian) of northeastern Honshu, Japan. - International Journal of Plant Sciences, 168: 341-350. https://doi.org/10.1086/510414

Tobe, H., Jaffre, T., Raven, P. H. (2000): Embryology of Amborella (Amborellaceae): descriptions and polarity of character states. - Journal of Plant Research, 113: 271-280.

https://doi.org/10.1007/PL00013935
Yamada, T., Nishida, H., Umebayashi, M., Uemura, K., Kato, M. (2008): Oldest record of Trimeniaceae from the Early Cretaceous of northern Japan. - BioMed Central Evolutionary Biology, 8: 135.1-135.7. https://doi.org/10.1186/1471-2148-8-135

Yamada, T., Imaichi, R., Kato, M. (2001): Developmental morphology of ovules and seeds of Nymphaeales. American Journal of Botany, 88: 963-974.

https://doi.org/10.2307/2657077 